University of Louisville

ThinkIR: The University of Louisville's Institutional Repository

Electronic Theses and Dissertations

1945

\title{
The absorption of carbon dioxide with a semi-plant scale packed tower.
}

Lewis P. Aker 1902-1981

University of Louisville

Follow this and additional works at: https://ir.library.louisville.edu/etd

Part of the Chemical Engineering Commons

\section{Recommended Citation}

Aker, Lewis P. 1902-1981, "The absorption of carbon dioxide with a semi-plant scale packed tower." (1945). Electronic Theses and Dissertations. Paper 1863.

https://doi.org/10.18297/etd/1863

This Master's Thesis is brought to you for free and open access by ThinkIR: The University of Louisville's Institutional Repository. It has been accepted for inclusion in Electronic Theses and Dissertations by an authorized administrator of ThinkIR: The University of Louisville's Institutional Repository. This title appears here courtesy of the author, who has retained all other copyrights. For more information, please contact thinkir@louisville.edu. 
UNIVERSITY OF LOUISVILLE

THE ABSORPTION OF CARBON DIOXIDE

WITH A SEMI-PLANT SCALE PACKED TOWER

\author{
A Thesis \\ submitted to the Faculty \\ of the Graduete school \\ of the University of Louisvilie \\ in Partial Fulfillment \\ of the Requirements \\ for the Degree of
}

MASTER OF CHEMICAL ENGINEERING

Department of Chemical Engineering

by

Lewis P. Aker

1945 
THE ABSORPTION OF CARBON DIOXIDE

WITH A SEMI-PIANT SCALE PACKED TOWER

Lewis P. Aker

Approved by the Examining Committeo:

Director

February, 1945 
CONTENTS

Page

List of Tables . . . . . . . . . . . . . . . . 111

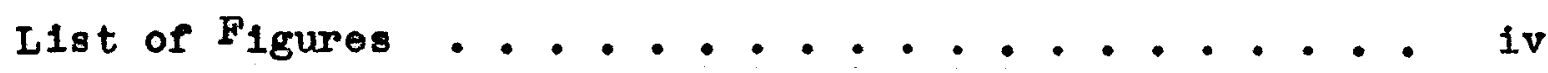
Abstract . . . . . . . . . . . . . . . . . v

Introduction . . . . . . . . . . . . . . . . . . I

Theoretical . . . . . . . . . . . . . . . 3

Apparatus . . . . . . . . . . . . . . . . 9

Analyt1cal Techniques . . . . . . . . . . . . 18

Date and Results.................... . . 23

Literature Cited . . . . . . . . . . . . . . 32

Appendix . . . . . . . . . . . . . . . . 35

Acknowledgments . . . . . . . . . . . . . . . . . . 54

V1ta. . . . . . . . . . . . . . . . . 56 


\section{LIST OF TABIES}

Table

No.

Titlo

Pago

1 Tabulation of Data . . . . . . .

2 "Theoretical" Variation of Transfer Coefficient with Temperature... . . 25

3 Water Meter Calibration Data....... 40 


\section{LIST OF FIGURES}

\begin{tabular}{|c|c|c|c|c|c|c|c|}
\hline No. & & T1t1e & & & & & Page \\
\hline 1 & Absorber . . . . . & $\cdot \cdot \bullet \cdot \cdot$ & - • & - • & & $\cdot \cdot$ & 11 \\
\hline 2 & Absorber Deta1ls. & $\cdot \cdot \bullet \cdot \bullet$ & - • & - • & & - & 13 \\
\hline 3 & Flow Diagrams & $\cdot \bullet \cdot \bullet \cdot$ & $\bullet$ & & & - $\bullet$ & 15 \\
\hline 4 & Transfer Coefficient & Variation & with & Wate & & Rate & 28 \\
\hline 5 & Transfer Coefficient & Variation & with & Temp & & ature & 30 \\
\hline 6 & Transfer Coefficient & versus Gas & Rete & $\theta$. & & $\cdot$ & 31 \\
\hline 7 & Calibration of Water & Flow Meter & - $\bullet$ & - . & & - & 41 \\
\hline
\end{tabular}


ABSTRACT

Carbon Dioxide is absorbed in water, using a semiplant soale absorber consisting of a $17 \mathrm{ft}$. length of $16^{\prime \prime} \mathrm{O} . \mathrm{D}$. pipe and packed with $3^{\prime \prime}$ spiral tile, stacked. Air is recirculated and $\mathrm{CO}_{2}$ added to the alr stream at the absorber inlet. Louisvilie city water is used as the absorbing medium. Constmuction detalls of the absorber are described. Water rates vary between $2,5501 b_{.} /($hr. $)\left(\right.$sq.ft.) and $13,5101 b_{\bullet} /($ hr. $)($ sq.ft.) and gas rates vary between $6 I$ and 240 lb./(hr.)(sq.ft.). Transfer coefficients $\left(K_{L^{a}}\right)$ are found that have oonsiderably higher values than would be expected from the work of other investigators. The equation for the transfor coefficient shows a variation proportional to the 0.85 power of the water rate

$$
\mathrm{K}_{\mathrm{L}^{2}}=.166\left(\mathrm{~L}_{\mathrm{S}}\right) \cdot 85
$$

No trend of transfer coefficient is found with varying gas rate. Most of data is obtained at $83^{\circ}$ F. with a few runs at lower temperatures. The trend of the coefficient with temperature is in the expected direction. 
INTRODUCTION 
The fleld of absorption, which is primarily the rew moval of a gaseous constituent or constituents from a gas stream by a liquid stream, has been covered extensively in the published 11terature. The majority of the published data, however, hes been obtained by using small scele apparatus, and from such data the performance of large scalo equipment has been predicted. The publication of actual data from plant scale equipment is rare (1). This condition is probably due to two factors. The first factor is that industrial equipment designers and operators prefer to ke日p their data to themselves, and the second factor is the difficulty, financial and physical, of constructing and operating plant-scale or semi-plant scale equipment in an educational institution.

While it is probable that design data based upon small scale equipment are applicable to equipment of any size, It is felt that there is need for more data on plant scale or semi-plant scele apparatus. Consequently, when it was found possible to construct and operate a semi-plant scale absorption tower, this work was attempted.

The packing avallable was threo inch spiral tilo and the tower a sixteen foot length of sixteen inch pipe. The system decided upon was the system carbon dioxide-water, mainly for reesons of convenience. 
THEORETICAL 
In the absorption or desorption of a gaseous constituent into or from a liquid phase, the most successful theory has been the so called "two film" theory. Th1s theory was suggested by Whitmen $(2,3)$ and has proved to be very useful in absorber design.

This two-film theory states that the principal rem sistance to mass transfor is the existence of two films of stagnant fluid with respect to one another, one on each side of the gas-11quid interface, and through which mass-transfer must take place by diffusion alone. The thicknesses of both the liquid and gaseous films are considered to be functions of the state of agitation of their respective phases. The concept is entirely analogous to the usuel treatment of heattransfer problems involving fluid phases.

The driving force which causes the mass transfer is the concentration difference, for the component in question, between the main body of the liquid and the interface and/or the partial pressure difference between the main body of the gas and the interface.

The following general equation expresses the rew lation between the mols transferred per unit area, the driving force and the resistance.

$$
-\frac{d N_{A}}{d A}=\frac{c_{1}-c_{L}}{r_{L}}=\frac{p_{G}-p_{1}}{r_{G}}
$$

It is noted that the resistance $r$ includes not only the resistance of the film but also the resistance from 
the body of the fluid to the fluid film, although the mor portion of the resistance is in the film.

In engineering calculations, however, the reciproeal of the resistance, known as the transfer coefficient is generally used.

$$
\begin{gathered}
k_{G}=1 / r_{G} \text { and } k_{L}=1 / r_{L} \\
-\frac{\mathrm{dN}_{A}}{\mathrm{~d}_{A}}=\mathrm{k}_{\mathrm{L}}\left(\mathrm{c}_{1}-\mathrm{c}_{\mathrm{L}}\right)=\mathrm{k}_{G}\left(\mathrm{p}_{\left.G-\mathrm{p}_{1}\right)}\right.
\end{gathered}
$$

It is assumed that at the true interface the two pheses are always in equilibrium (4). This means that $p_{1}$ is in equilibrium with $C_{1}$ and that $P_{1}$ is a function of $C_{1}$.

It is rather difficult to evaluate the transfer coofficlents for the individual phases, so overall coefficients are used very extensively in engineering design.

$$
-\frac{d N_{A}}{d A}=K_{L}\left(c *-c_{L}\right)=K_{G}(p \theta-p *)
$$

Eitier overell coefflcient $\left(K_{G}\right.$ or $\left.K_{L}\right)$ may be used in any particular instance. In the case of very soluble gases the major portion of the resistance is in the gas film so that $\mathrm{K}_{G}$ is usually used. Where the solubility of the gas is low, the liquid film controls and $\mathrm{K}_{\mathrm{L}}$ is usually used.

For the system carbon dioxide-rater, the major resistance (5) is in the liquid film and thus the liquid basis overall coefficient is indicated as the besis for calculation. is oquation III is valid only for an infinitesmal 
portion of an absorption tower, it is not applicable until 1t can be evaluated over the whole system by graphical integration or other means.

Where concentrations of the solute gas are low in both the gaseous and liquid phases, it is very convenient to use the calculation system of Gilliland (6). In this system, the liquid concentrations are expressed as $\mathrm{X}$, the mols of solute per mol of solute-free solvent, and the gas concentrations as $Y$, the mols of solute in the gas phase per mol of solute-free gas $\left(Y=P_{A} / P-P_{A}\right)$. The liquid rate through the apparatus is expressed as $\mathrm{I}$, the mols of solute-pree liquid per hour and the gas rate is expressed as $G$, the mols of solute-free gas per hour.

In using this system, the "operating line" of an absorber, plotted in terms of $X$ and $Y$ is a straight line. (see Equation VI) Also, the equilibrium curve for systems following Henry's law will be a stralght line when plotted on the same coordinates.

In such a case, the integration of the driving force from top to bottom of the tower becomes a simple thematical calculation.

In any given crossection of an operating absorption tower, with steady rates of flow, the amount of solute absorbed by the liquid must equal the amount given up by the gas.

$$
\operatorname{GdY}=\operatorname{LdX}
$$

If we consider the gas and liquid concentrations 
at the top of the tower to be represented by $X_{2}$ and $Y_{2}$, and the concentrations at the bottom of the tower to be reprew sented $X_{1}$ and $Y_{1}$, integration of equation IV between the bottom and top of the tower (allowable under steady condition)

$$
G\left(Y_{1}-Y_{2}\right)=I\left(X_{1}-X_{2}\right)
$$

Also integration between the top of the tower and any crossection of the tower where concentrations are $X$ and $Y$ produce.

$$
G\left(Y-Y_{2}\right)=L\left(X-X_{2}\right)
$$

From these conditions, with steady flow, $Y$ must be linear in $x$.

$$
\begin{aligned}
& \text { Expressing equation III in terms of } X \text { and } Y \\
& -\frac{d N_{A}}{d H}=K_{L X}(X *-X)=K_{G Y}(Y-Y *) \\
& \text { In this equation } K_{L X} \text { is } K_{L} \text { expressed in terms of }
\end{aligned}
$$
$X$ instead of $c$ and $K_{G Y}$ is $K_{G}$ expressed in terms of $Y$ instead of p. X* represents liquid concentration in equilibrium with the body of the gas and $Y *$ gas concentretion in equilibrium with tre body of the 11quid.

$$
\text { If "a" represents tho interfecial area of contact }
$$
between gas and liquid in square feot per cublc foot in the absorber and $S$ represents the cross-sectional area of the absorber, then

$$
\mathrm{dA}=\mathbf{a s d}
$$

where 1 represents the height of the tower. Also

$$
\begin{aligned}
-\mathrm{dN}_{\mathrm{A}} & =\mathrm{LdX} \\
-\frac{\mathrm{dN}}{\mathrm{A}} & =\frac{\mathrm{LdX}}{\mathrm{aSdI}}
\end{aligned}
$$


Combining equations VII and VIII,

$-\mathrm{dN}_{\mathrm{A}}=\mathrm{IdX}=\mathrm{K}_{\mathrm{IX}}$ as $(\mathrm{X} *-\mathrm{X}) \mathrm{dl}$

Intsgrating equation IX betwoen top and bottom of the tower,

$$
I\left(X_{1}-X_{2}\right)=K_{L X} \text { aSI }(\Delta X) a v
$$

where $(\Delta \mathrm{X})$ av is the logarithmic mean of the driving forces at the top and bottom of the tower.

Equation $X$ is applicable only if the equilibrium curve, plotted 1r. $X$ and $Y$, is a straight line over the range in which it is involved so that the value of $(X *-X)$ is Iinear with respect to the distance from the top of the tower.

Since the system carbon dioxido-water follows Henryts Law (7) and since carbon dioxide is not very soluble in water, all data in this work have been calculated in terms of $K_{L} X^{a}$ using equation $X$ and tren recalculated to $K_{L}$ for comparison with other work. 
APPARATUS 
As shown in figure 1, the absorption tower is cone structed of a length of 16 inch 0. D., $3 / 8$ inch wall, stool pipe. One end (the bottom end) is "bull-headed" with an "orange poel" weld, the other end swedged down to standard 6 inch pipe and flanged. At the bottom of the tower are welded two flanged 4 inch pipe openings, at right angles to each other for gas inlet and liquid outlet. Six inspection and packing openings are spaced along the length of the tower and consist of short standard 6 inch pipe nipples welded into the shell, flanged, and closed with companion flanges. The gas outlet at the top is a flanged 4 inch standard plpe wolded to the swedged portion of the shell and placed as high as possible. At the lower end, just above the gas inlet opening, a grid is welded inside the shell to support the packing. The tower is supported at the bottom by a ring of 12 inch pipe and at the top by clamp attached to the bullaing framework. Attached to the liquid outlet is seal pot made of 12 inch pipe, closed on both ends, with a 4 inch inlet and outlet.

The pecking consists of 3 inch, corrugated spiral rings which are ceramic cylinders, throe inches in diameter and throe inches high (about), with spiral web in the conter. These rings are packed in the tower, 19 to a layer, w1th the axes all parallel to the axis of the tower. The arrangement of an individual layer is shown in figure 2 . In oach successive layer of packing, the axis of each individual tile In the outer circle is placed above the edge of a tile in the layer below, as shown by the dotted circles in the packing 


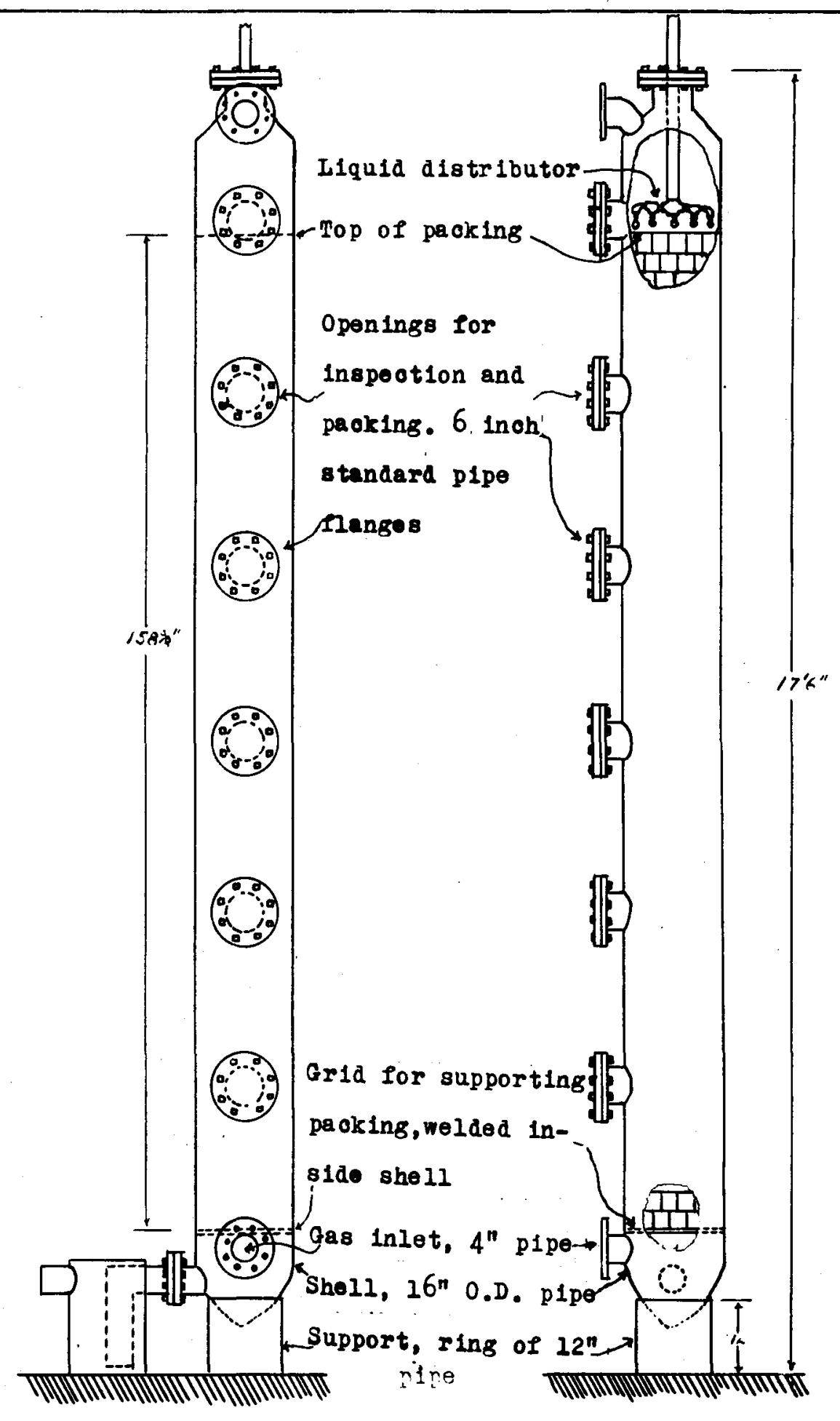

Fioure 1, APSOPQAR 
crossection of figure 2 .

The height of the packing is $1583 / 8$ inches, consisting of 51 layers, 19 tile to a layer, making a total of 969 individuel units.

Perry (8) gives the following data for $3 \times 3$ corrugated spiral rings.

\begin{tabular}{|c|c|c|c|c|}
\hline Dumped & $\begin{array}{l}\text { \% Freo } \\
\text { Spe ce } \\
72\end{array}$ & $\begin{array}{c}\text { Surface } \\
\text { so.ft./cu.ft. } \\
22\end{array}$ & $\begin{array}{l}\text { Wt.\#/ } \\
\text { cu.ft. } \\
40\end{array}$ & $\begin{array}{l}\text { Units/ } \\
\text { cu.ft. } \\
48\end{array}$ \\
\hline Stacked & 64 & 29 & 53 & 63 \\
\hline Sherwood \& Holloway & (9) & & & \\
\hline Dumped & & & & 48 \\
\hline Stacked & 59 & 42 & & 62 \\
\hline Butcher (10) & & & & \\
\hline Stacked & 64 & 29 & 53 & 64 \\
\hline
\end{tabular}

In this case with 1.27 square foet crossection and packing helght of $1583 / 8$ inches, there are $16.77 \mathrm{cu}$.ft. of packing or 57.8 units/cu.ft.

Several tile wore measured and examined by W. F. Durbin (II) and gave an average of $0.443 \mathrm{sq} . \mathrm{ft}$. of surface per unit. This gives a surface area of the packing of 25.6 sq.ft./cu.ft.

The inner surface of the tower is 52.5 sq.ft. from the top of the packing to the supporting grid. Surface area of the grid is assumed to be 2 sq.ft. Total area for absorption, dry, is $483.5 \mathrm{sq}$. ft. or $28.83 \mathrm{sq} . \mathrm{ft} . / \mathrm{cu} . \mathrm{ft}$. 

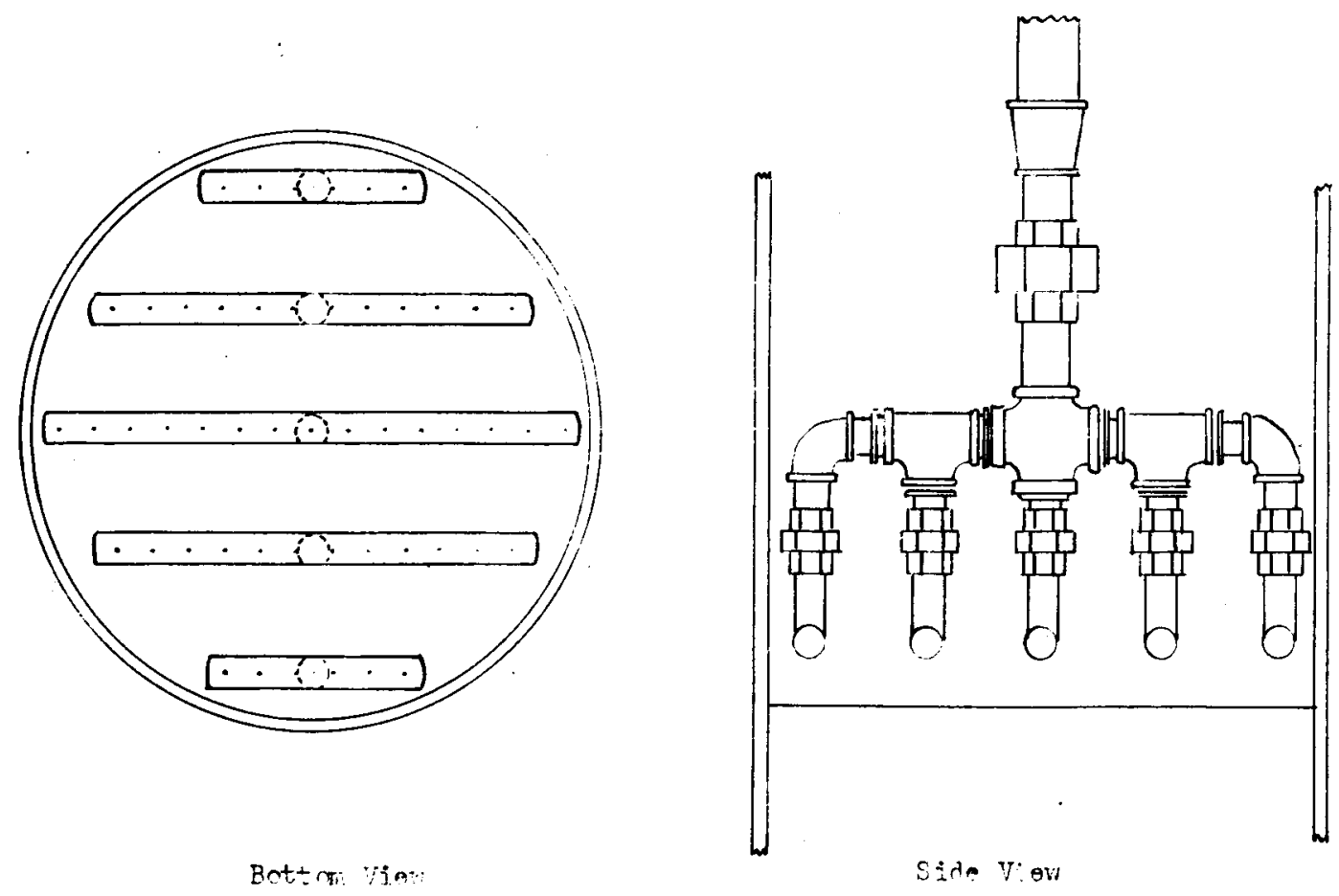

Loolid Distrinutor 
The 11quid distributor at the top of the tower is a "christme tree" made up of five sections of standard $1 / 2$ Inch pipe, each section having the ends wolded closed and a short, threaded, nipple welded at right angle in the center. The middle section 1 s 14 inches long, the sections on elther side of the middle are ic inches long, and the outside sections are 6 inches long. Each section has a series of holes, $1 / 8$ inch in diameter, and spacod 1 inch apart, making a total of fifty $1 / 8$ inch holes with a total area of $0.613 \mathrm{sq.} \mathrm{in.}$ The liquid line entering the tower is standard $11 / 4$ inch pipe which is reduced to 1 inch pipe fust before entering the "Christmes tree", which, In addition to the sections described is composed of 1 inch cross, two $3 / 4$ inch tees, two $1 / 2$ inch elbows, various bushings, short nipples and unions. The assembly is shown in figure 2.

The flow-meter for the gas (Inlet) consists of 1.125 inch, sharp edged orifice in a 4 inch standard pipe flange, with throat connections.

The Ilquid flowmeter consists of 0.703 inch sharp edged orifice in a standard 2 inch pipe flange, with throat connections.

The orifices for both flow meters were from $1 / 8$ inch stainless $(18-8)$ steel plate.

The gas to be treated was forced thru the tower with a 4-A $\mathrm{K}_{\text {oots }}$ Acme blower. No liquid pump was used as the Ilquid was Louisville c1ty water and the prossure avail- 

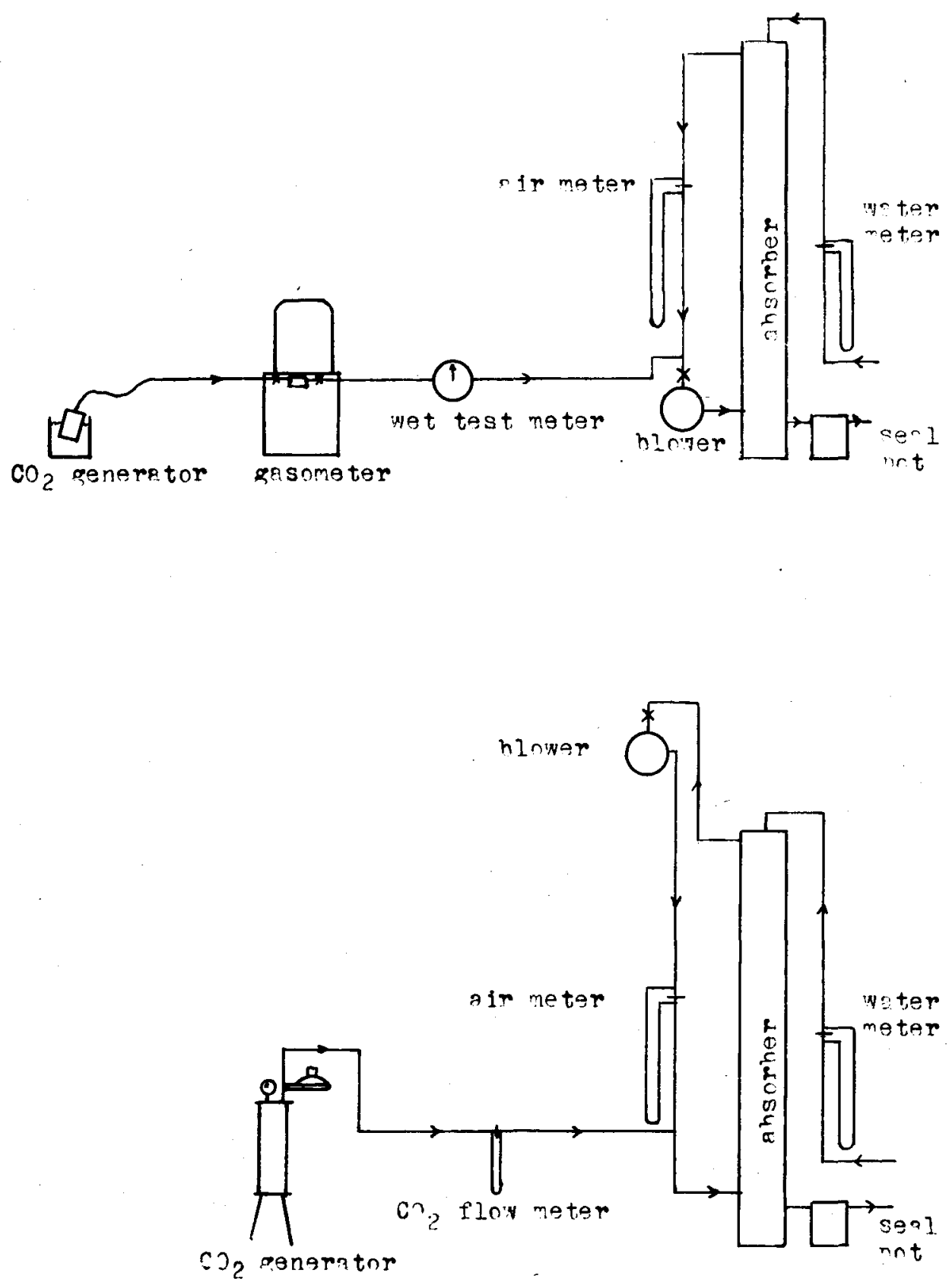
ablo gave sufficient capacity without a pump.

A six cu.ft. "meter-prover", borrowed from the

Louisville Gas and Electric Company was used as a carbon dioxide storage holder on a few of the runs. Solid carbon dioxide was placed in a one gallon can equipped with a press I1d to which was attached a hose connected to the "holder". As the carbon dioxide veporized it pessod into the "holder" and was withdrewn at atmospheric pressure into the gas stream during the run.

In the rest of the runs a pressure vessel equippod with a safety valve and a gas pressure regulator was used as as \& generator. The vessel was filled with solld carbon dioxide, the $11 \mathrm{~d}$ bolted on and the gas pressure regulator used to hold a constant gas pressure of a $f \in w$ inches of water at the outlet of the vessel.

A one-tenth cubic foot wet test meter and a small flowmeter, consisting of a $13 / 64$ inch orifice in $9 / 16$ inch I.D. copper tubing, were used to measure the gaseous carbon dioxide entering the tower.

In the first series of runs (Runs 1 to 3 inclusive), the setup indicatod in top flow diagram of figure 3 was used. The eir pump was conrected directly into the bottom of the tower and the gas outiet from the top of the tower was connected to the suction side of the pump with the gas flowmeter between the tower outlet and the pump inlet. Gaseous carbon dioxide, after pessing the wet test meter, was introduced 
Irto the gas stroam at the auction side of the pump.

It was intended, with this layout, to introduce carbon dioxide at a constant rate until equilibrium was established within the tower, at which time the absorption rato would equel the rate at which the carbon dioxide was belng added. Under these conditions, therefore, it should only be necessary to measure the carbon dioxids concentration of the gas leaving ths tower, and the concentrations of the liould entering and leaving the tower. These assumptions were the basis of the calculations in this series of runs.

The remeinder of the runs were made with the apparetus arranged as shown in the lower flow diagram in figure 3. The change in layout was necessitated by a change in 10cation of the equipment. In runs 4 to 17 tests were made on liquid entering and leaving the tower and on the gas entering and leaving.

In all runs, Louisville city water was passed through the tower at various rates, a1r was pumped at various rates and gaseous carbon dioxide passed into the gaseous stroam at the tower inlet. The rango of the variations was limited by the range of the manometer avallable for the liquid flowmeter and by the capacity of the Roots blower. 
ANALYTICAI TECHNIQUES 
The first tochnique used in anelyzing the gaseous phase was to fill with water an ohrlonmoyer flask, fitted with a two hole stopper and glass tubes, and displace the water with the gas to be tested. First the inlet of the flask was closed with a clamp and then the outlet, leaving the gaseous sample at atmospheric pressure. As soon as possible after sampling, $10 \mathrm{ml}$ of a standard barium hydroxide solution was introduced with a pette, by releasing both inlet and outlet clamps on the sample flask and draining the pipette into the flask thru the tube leading to the bottom of the flask. Both openings were then closed and the flask shaken for five minutes. Then the stopper was removed, the stopper and tubes washed with freshly bolled and cooled distilled water, all washings being caught in the sample flask. The excess of barlum hydroxide was titreted with standard hydrochloric acid, using phenolphthalein as indicator. From the volume of the flask, the barometric pressure, the temperature of the room, the titration and a blank titration, the percentage of carbon dioxide in the sample was calculated. For the calculation, the volume of the flask, minus $10 \mathrm{ml}$, was used as the sample volume.

This technique gave accurate results (presumebly) but was too time consuming and was used on runs 1 and 2 only. on all runs except runs 1 and 2 , a single pipette "Orsat" type gas analysis apparatus was used, consisting of a burette and leveling bottle and a contact plpette fllled with 
$40 \%$ potassium hydroxide. Water was used as the confining medium in the burette.

The first teohnique used for determining the carbon dioxide conoentration in the liquid phase was used in runs 1 to 3 only. The sampling tube was held near the bottom of a $300 \mathrm{ml} \mathrm{B.O.D.} \mathrm{bottlo} \mathrm{and} \mathrm{several} \mathrm{times} \mathrm{the} \mathrm{volume} \mathrm{of} \mathrm{the} \mathrm{bottle}$ was permitted to flow before the sampling tube was removed. The stopper was immediately inserted after sampling. As soon as possible after sampling, the stopper was removed and $25 \mathrm{ml}$ of a standard barium hydroxide solution wero added with a plpette. The tip of the pipette was lowered nearly to the bottom of the bottle, drained and then slowly removed. The stopper was replaced, the bottle rotated to mix the sample and reagent, and then the whole sample dumped into a large flask, which had been previously swept out with $\mathrm{CO}_{2}$-free air, and the excess of barlum hydroxide titrated with standard hydrochlorio acid. The volume of the bottlo, minus $25 \mathrm{ml}$, was considered the volume of the sample. A blank titration was made on a similar sample of freshly bolled and cooled distilled water. This method was also discarded as being too time-consuming although it should give quite accurate results.

On muns 4 and 5 , and on several runs not reported, a testing system for the liquid phase was adopted and which proved to be generally unsuccessful. A relation (12) between the $\mathrm{pH}$, free $\mathrm{CO}_{2}$ and the alkalinity of water, was found which seemed to be made to order for speed and accuracy as a 
glass-electrode $\mathrm{pH}$ meter of the best industrial type was avallable. All that appeared to be necessary was to test inlet and outlet for $\mathrm{pH}$ and ane an occassional alkalinity titration. From the relation,

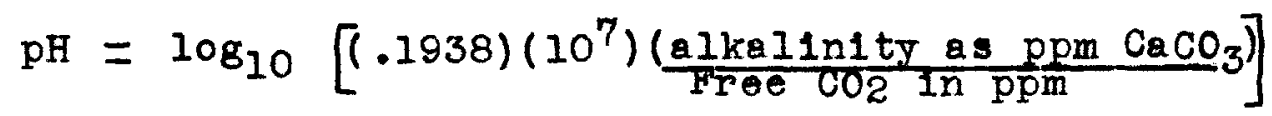

the froe $\mathrm{CO}_{2}$ could be readily calculated. This method may be good for approximate froe $\mathrm{CO}_{2}$ determinations, but data calculated from this relation gave negative driving forces at the bottom of the tower in most instances.

Runs 4 and 5 are also the only runs in the serles in which the air from the outlet of absorber was not led to the a ir pump inlet. In these two runs the air from the room was taken into the alr-pump suction and the alr loaving the absorber discharged into the room.

on the remainder of the runs a modification of the standard (13) water-laboratory titration for free $\mathrm{CO}_{2}$ was used. A $100 \mathrm{ml}$ pipette was connected to the sampling tube and the water allowed to flow through the pipette until several hundred milliliters had passed through it. The pipette was then disconnected, adjusted to the mark and the sample transferred to a $300 \mathrm{ml}$ flask which contalned almost enough standard sodIurn hydroxide solution (as determined by a previous titration) to react with the froe $\mathrm{CO}_{2}$ in the sample. The tip of the pipette was led below the surface of the standard solution when transferring the sample. Then phenolphthalein was added and the titration completed by adding standard sodium hydroxide 
solution until a faint permanent pink was attained. This method does not completely correct for the interference of the $\mathrm{CO}_{2}$ in atmosphere but should give the difference in free $\mathrm{CO}_{2}$ between the inlet and outlet waters fairly accurately. 
DATA AND RESULTS 


\begin{tabular}{|c|c|c|c|c|c|}
\hline Run \# & $\begin{array}{c}\text { Water } \\
\text { Temperature }\end{array}$ & $\begin{array}{l}\text { Water Meter } \\
\text { Differential } \\
\text { Inches of } \\
\text { Mercury }\end{array}$ & $\begin{array}{l}\text { Water Rate } \\
\# / h r .\end{array}$ & $\begin{array}{c}\mathrm{I}_{\mathrm{S}} \\
\text { Water Rate } \\
\# /(\mathrm{hr})(\mathrm{sq} . \mathrm{ft})\end{array}$ & $\begin{array}{c}\text { I } \\
\mathrm{mols} / \mathrm{hr} .\end{array}$ \\
\hline 1 & 51 & 9.06 & 9,510 & 7,490 & 528 \\
\hline 2 & 53 & 1.05 & 3,235 & 2,550 & 180 \\
\hline 3 & 65 & 4.1 & 7,020 & 5,520 & 390 \\
\hline $.4 *$ & 54 & 4.4 & 6,620 & 5,210 & 368 \\
\hline $5 *$ & 54 & 13.85 & 11,750 & 9,250 & 653 \\
\hline 6 & 83 & 4.2 & 6,475 & 5,090 & 360 \\
\hline 7 & 83 & 12.3 & 11,080 & 8,720 & 615 \\
\hline 8 & 83 & 29.55 & 17,170 & $\cdot 13,510$ & 953 \\
\hline 9 & 83 & 2.4 & 4,890 & 3,850 & 272 \\
\hline 10 & 83 & 1.05 & 3,240 & 2,550 & 179.9 \\
\hline 11 & 83 & 8.35 & 9,120 & 7,180 & 507 \\
\hline 12 & 83 & 20.15 & 14,250 & 11,220 & 791 \\
\hline 13 & 83 & 14.90 & 12,190 & 9,600 & 667 \\
\hline 14 & 83 & 23.07 & 15,180 & 11,930 & 843 \\
\hline 15 & 83 & 29.18 & 17,080 & 13,430 & 947 \\
\hline 16 & 83 & 11.65 & 10,780 & 8,500 & 598 \\
\hline 17 & 83 & 5.7 & 7,540 & 5,930 & 418 \\
\hline
\end{tabular}

* On these two runs, the air leaving the absorber was not reciroulated. Air pump inlet received air from the room. 


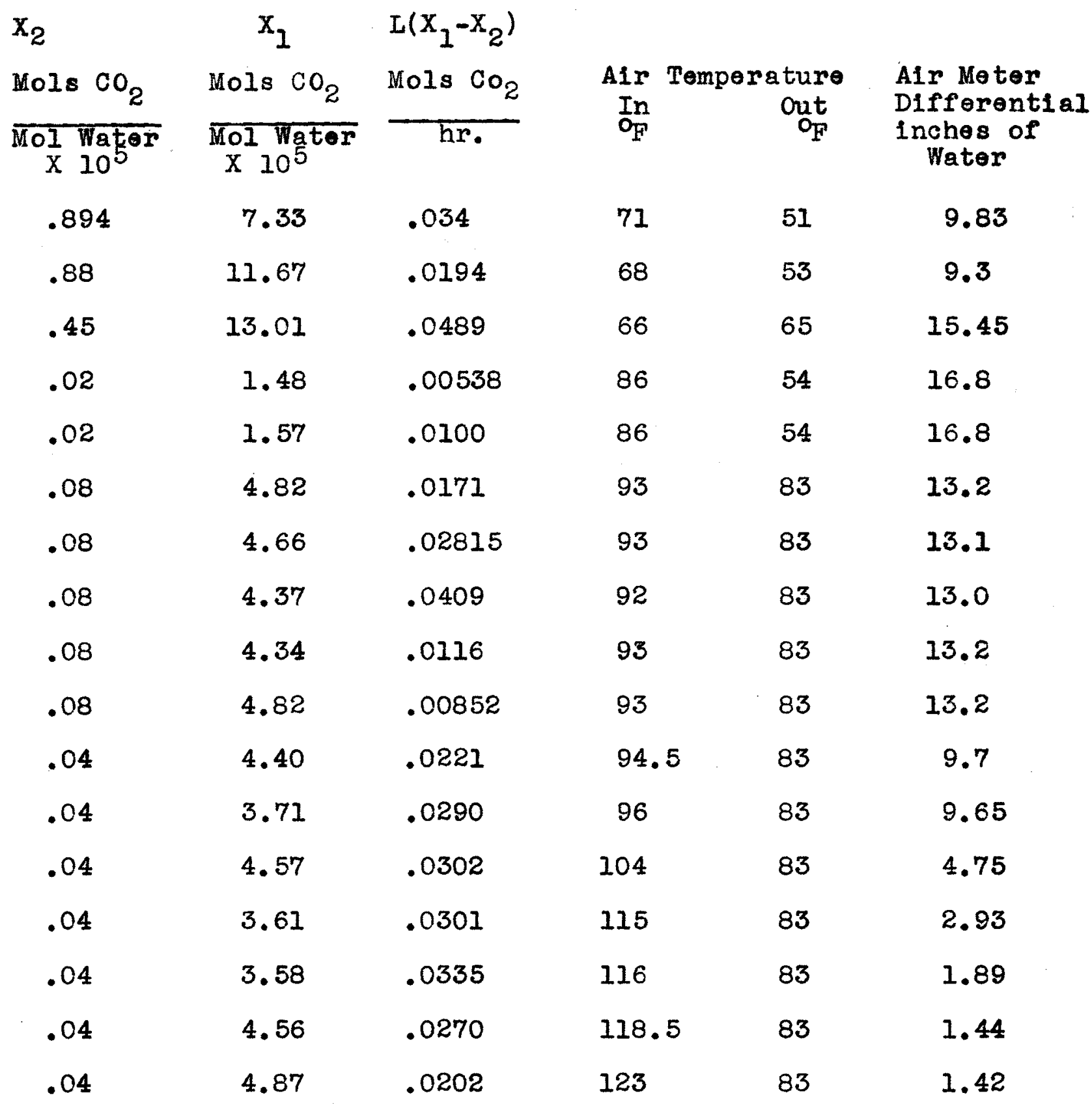




\begin{tabular}{|c|c|c|c|c|c|}
\hline $\begin{array}{l}\text { Air Rate } \\
\# / \mathbf{h r}\end{array}$ & $\begin{array}{l}\mathrm{G} \\
\text { Mols } / \mathrm{hr} \\
\text { of COR } \\
\text { freo alr }\end{array}$ & $\begin{array}{c}\mathrm{Y}_{1} \\
\text { Mols } \mathrm{CO}_{2} 2\end{array}$ & $\begin{array}{c}\mathrm{Y}_{2} \\
\text { Mols CO} 2\end{array}$ & $\begin{array}{l}G\left({ }_{1}-Y_{2}\right) \\
\frac{\mathrm{Mols}_{\mathrm{SO}} \mathrm{CO}_{2}}{\mathrm{hr} .}\end{array}$ & $\begin{array}{l}\mathrm{K}_{L X^{\mathrm{a}}} \\
\frac{\# \text { mols }}{(\mathrm{hr})(\mathrm{cu.ft})(\Delta \mathrm{X})}\end{array}$ \\
\hline 242.5 & 7.31 & .1031 & .0984 & .034 & 53.7 \\
\hline 238.5 & 6.81 & .162 & .159 & .020 & 25.6 \\
\hline 313 & 8.08 & .236 & .229 & .057 & 61.15 \\
\hline 305 & 10.52 & .0194 & .0183 & .011 & 51.8 \\
\hline 305 & 10.52 & .0225 & .0204 & .0221 & 73.6 \\
\hline 275.5 & 8.35 & .1021 & .0994 & .0225 & 60.8 \\
\hline 274 & 8.4 & .0950 & .0916 & .0285 & 127.0 \\
\hline 273.5 & 8.45 & .0917 & .0863 & .0455 & 159.2 \\
\hline 275.5 & 8.51 & .0882 & .0863 & .01618 & 48.5 \\
\hline 275.9 & 8.44 & .0974 & .0951 & .0194 & 41.8 \\
\hline 235.1 & 7.26 & .0902 & .0872 & .0218 & 95.0 \\
\hline 233.3 & 7.36 & .0763 & .0708 & .0405 & 144.8 \\
\hline 163 & 5.01 & .0963 & .0901 & .0310 & 112.8 \\
\hline 126 & 4.01 & .0754 & .0659 & .0380 & 147.3 \\
\hline 101 & 3.21 & .0811 & .0664 & .0471 & 129.0 \\
\hline 88.2 & 2.73 & .0989 & .0854 & .0368 & 98.6 \\
\hline 87.5 & 2.69 & .1011 & .0921 & .0242 & 83.5 \\
\hline
\end{tabular}




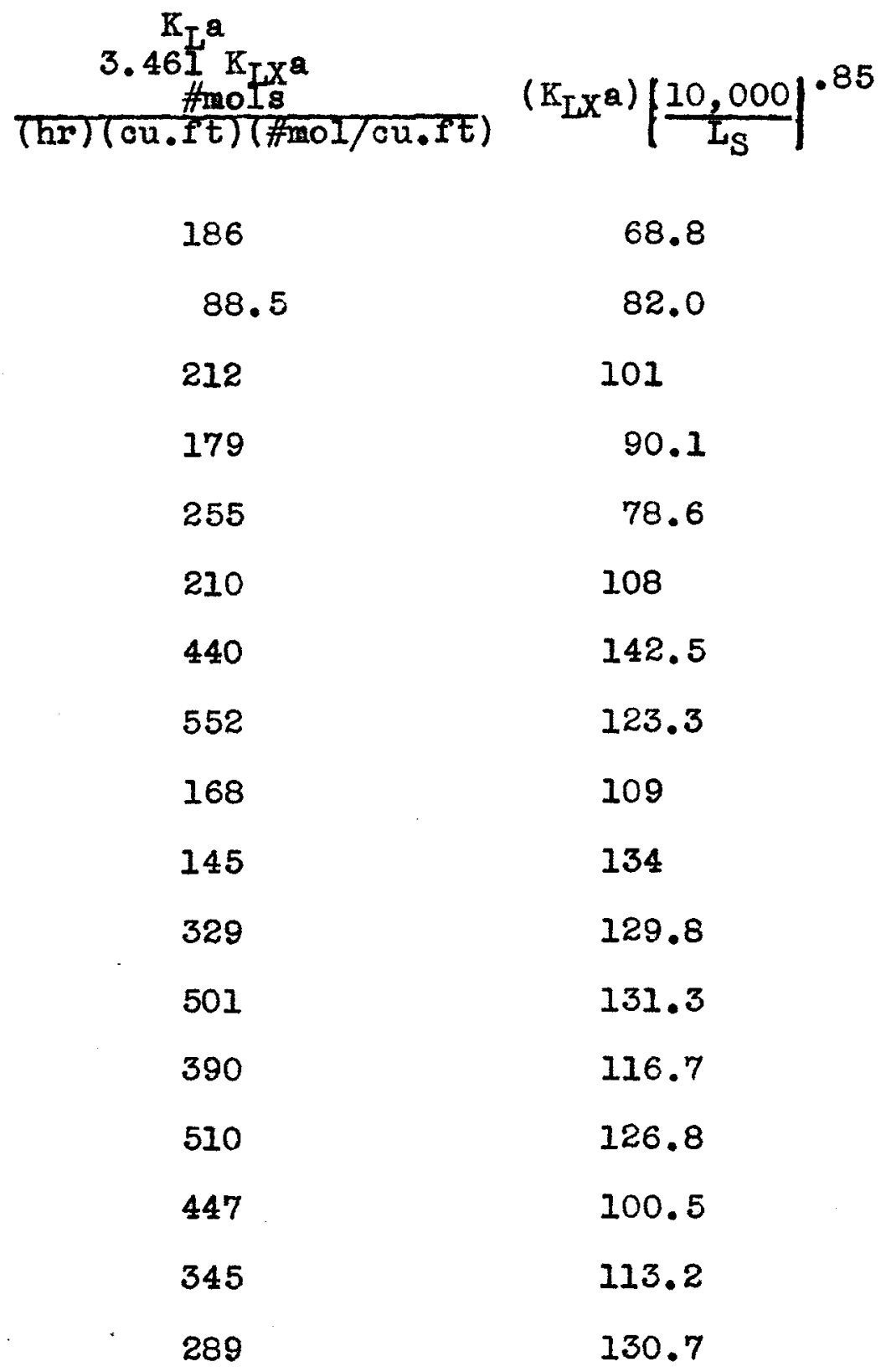




\section{TABLE 2}

"THEORETICAL" VARTATION OF TRANSFER COEFFICIENT WITH TEMPERATURE

\begin{tabular}{|c|c|c|c|}
\hline $\begin{array}{c}\text { Temperaturo } \\
\text { in }\end{array}$ & $\begin{array}{c}\text { Viscosity } \\
\text { In Centipolses } \\
\mu_{*}\end{array}$ & $\left(\begin{array}{c}\text { Viscosity } \\
(\text { in Centipoises }\end{array}\right)^{\frac{3}{2}}$ & $\begin{array}{l}\text { Caloulated value } \\
\text { of }\left(\mathrm{K}_{\mathrm{IX}^{\mathrm{a}}}\right)_{10,000}\end{array}$ \\
\hline 83 & .830 & .764 & 121 \\
\hline 80 & .861 & .799 & 116 \\
\hline 75 & .917 & .876 & 106 \\
\hline 70 & .978 & .965 & 96 \\
\hline 65 & 1.045 & 1.07 & 86.5 \\
\hline 60 & 1.12 & 1.18 & 78 \\
\hline 55 & 1.21 & 1.33 & 69.5 \\
\hline 50 & 1.31 & 1.50 & 61.6 \\
\hline
\end{tabular}

Note: Value of $\left(\mathrm{K}_{\mathrm{LX}^{a}}\right)_{10,000}$ for $83^{\circ} \mathrm{F}$ taken from ourve of figure 4, other values calculated as follows $\left(K_{I_{X}}{ }^{a}\right)_{10,000}$ $=(121) \quad \frac{.764}{\left(\mu_{*}\right) 3 / 2}$ 
A summary of the data is shown in table 1. The material balances are none too good in many of the runs as shown by comparison of the values of $L\left(X_{1}-X_{2}\right)$ and $G\left(Y_{I}-I_{2}\right)$. As a silght error in the measurement of the concentration of $\mathrm{CO}_{2}$ in the gas phase would make a large error in $G\left(Y_{1}-Y_{2}\right)$, in the caloulations where poor agreement was obtained the value of $L\left(X_{1}-X_{2}\right)$ was used as being considered the more re11able.

On all runs the value of $K_{L X}$ was calculated by the methods of Walker, Lewis, Mcadams and Gilliland (6) and then recaloulated to the usual $\mathrm{K}_{\mathrm{L}^{\mathrm{a}}}$ by multiplying by the factor $62.3 / 18$ as $K_{L X}$ is expressed as $1 \mathrm{~b} . \operatorname{mols} /(\mathrm{hr}$.$) (cu.ft.)$ $(1 \mathrm{~b} \cdot \mathrm{mols} / 1 \mathrm{~b} \cdot \mathrm{mol})$ and $\mathrm{K}_{\mathrm{L}}$ a as Ib.mols/(hr.)(cu.ft.)(Ib.mols/ cu.ft.). For the liquid phase used (water) the ratio cu.ft./1b.mol is $62.3 / 18$.

In figure 4, the values of $\mathrm{K}_{\mathrm{L}}$ a are plotted as well as data obtained by others (14). The solid Iine represents the data obtained at $83^{\circ} \mathrm{F}$ and the equation of the line is

$$
\mathrm{K}_{\mathrm{L}}^{\mathrm{a}}=.166\left(\mathrm{~L}_{\mathrm{S}}\right) \cdot .85
$$

Assuming from this equation that the value of $K_{L X}{ }^{a}$ is proportional to the .85 power of $I_{S}$, it should be possible to reduce all figures for $K_{L X} X^{a}$ to the basis of a common. water rate so as to study the effect of temperature. The value of $K_{\mathrm{IX}^{2}}$ at a water rate of $10,0001 \mathrm{bs} \cdot /(\mathrm{hr} \cdot)\left(\mathrm{sq} \cdot \mathrm{ft}_{\bullet}\right)$ is the final colum of figures in table 1 , and is listed as $\left(\mathrm{K}_{L X^{2}}\right)_{10,000}$

$$
{ }_{L X^{a}}^{\left(K_{10,000}\right.}=K_{I X^{a}}\left[\frac{10,000}{L_{S}}\right]^{.85}
$$


These values of $\left(K_{L X}{ }^{8)} 10,000\right.$ are plotted in figure 5 for all those runs not made at $83^{\circ} \mathrm{F}$, $a 11$ the runs at $83^{\circ} \mathrm{F}$ being represented by a single composite point. This composite point was obtained by taking the value of $K_{L}$ at $83^{\circ} \mathrm{F}$ from the curve in figure 4 and reconverting this value to $K_{L X}{ }^{a}$ by multiplying by $18 / 62.3$.

According to walker, Lewis, Mckdems and Gilliland (15), diffusivity in the liquid phase is approximately proportional to the inverse three-halves power of the viscosity. Since the transfer coefficient is proportional to the diffusivity, when the liquid film thickness is uniform, as it would be with a uniform liquid velocity, at constant temperature, then the value of $\mathrm{K}_{L X}$ or $\mathrm{K}_{I X^{2}}$ should be proportional to the inverse three-halves power of the viscosity.

Taking as the inltial point the composite point for runs 6 to 17 in figure 5, points for a "theoretical" curve for the variation of $\mathrm{K}_{I X^{2}}$ with temperature were calculated and listed in table 2 , and plotted in figure 5 .

It w11l be noted that the trend of $\mathrm{K}_{\mathrm{LX}} \mathrm{x}^{\mathrm{a}}$ follows this "theoretical" curve fairly well, indicating that the varlation of the transfer coefficient with temperature is probably a function of liquid viscosity.

In figure 6 , the values of $\left(\mathrm{K}_{\mathrm{LX}}{ }^{\mathrm{a}}\right)_{10,000}$ at $83^{\circ} \mathrm{F}$ are plotted against the gas rate so as to ascertain any trend due to gas rate. No such trend is noted so that it nuy safely be said that this work indicates that there is no noticeable effect on the transfer coefficient due to variation in the 


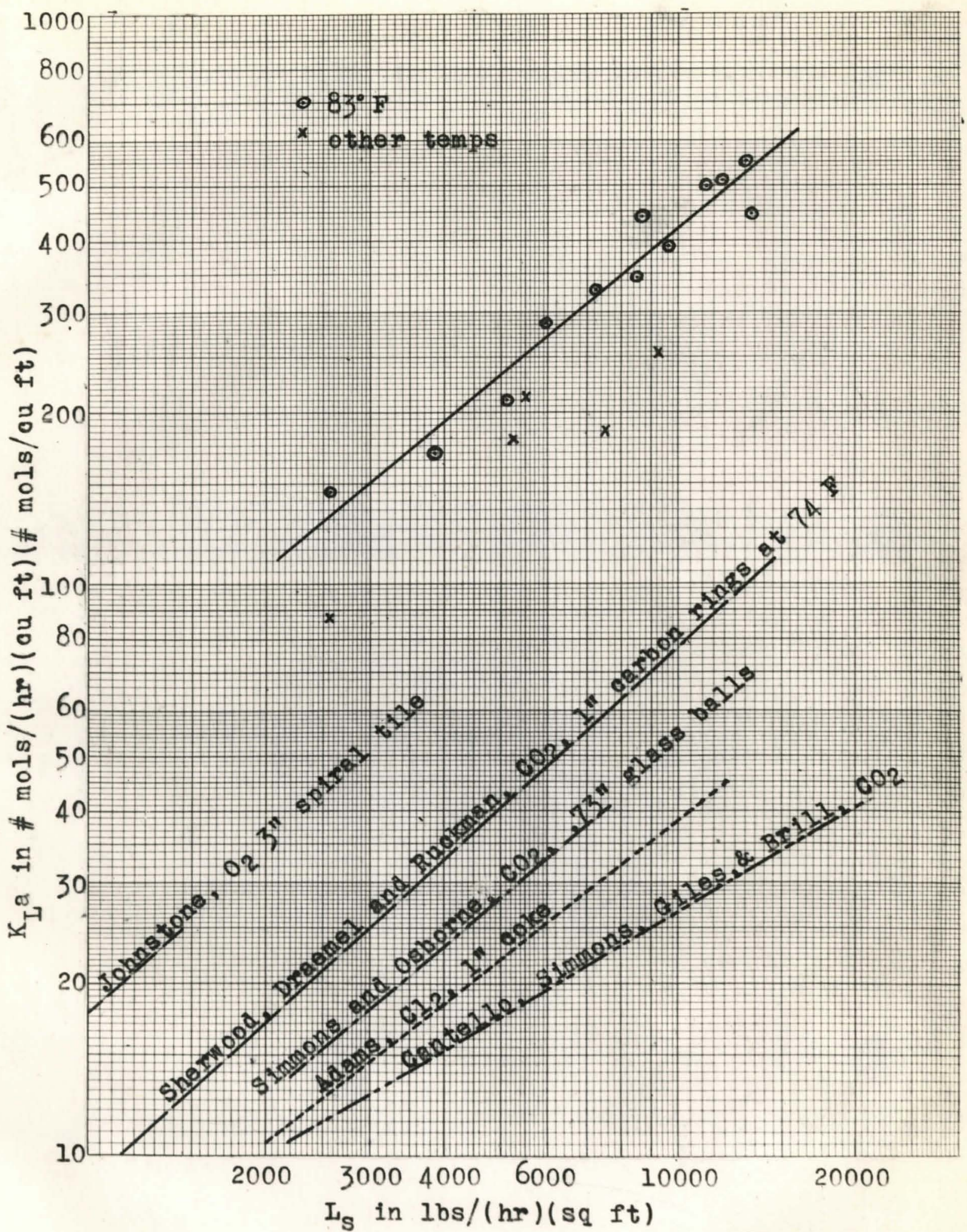

Figure 4, Transfer Coefficient Variation with Water Rate 
gas rate. The most noteworthy feature of the data for $\mathrm{K}_{\mathrm{L}}{ }^{2}$ In figure 1 is the very high values obtained in this work compared with that of other observers. The only explanation that comes to mind is that the cereful stacking of the tile used in this work may be at least a partial cause.

It is recommended that further data with this same apparatus be made by other observers so that the values may be either corroborated or discredited.

By making series of runs at several seasons of the year the temperature may be chosen at will over the range of city water temperatures, which will vary from $40^{\circ}$ in late winter to $85^{\circ}$ in late summer. These temperatures vary slowly and tend to remein fairly constant for several days at a time. 


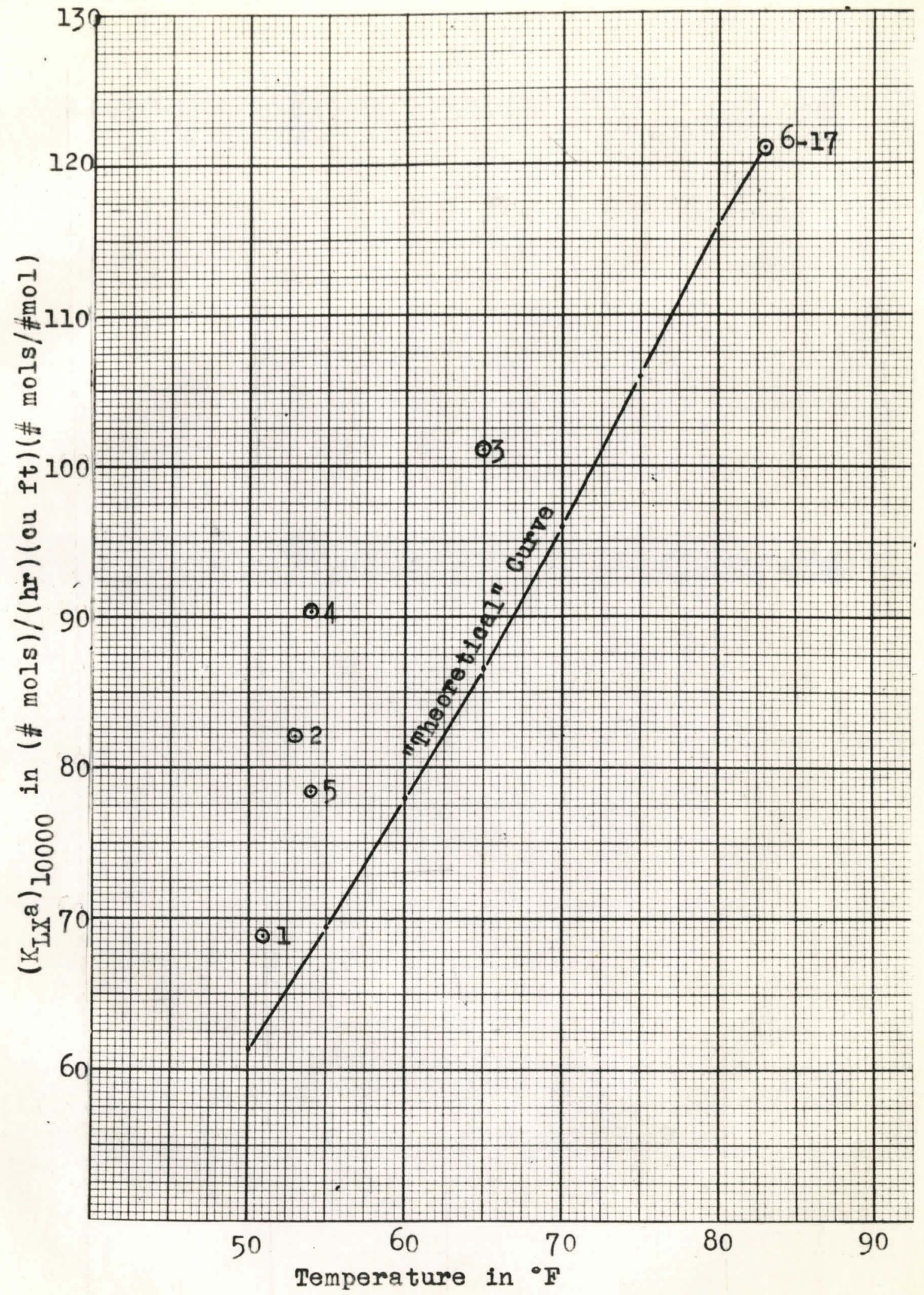

Figure 5, Transfer Coefficient Variation with Temperature 


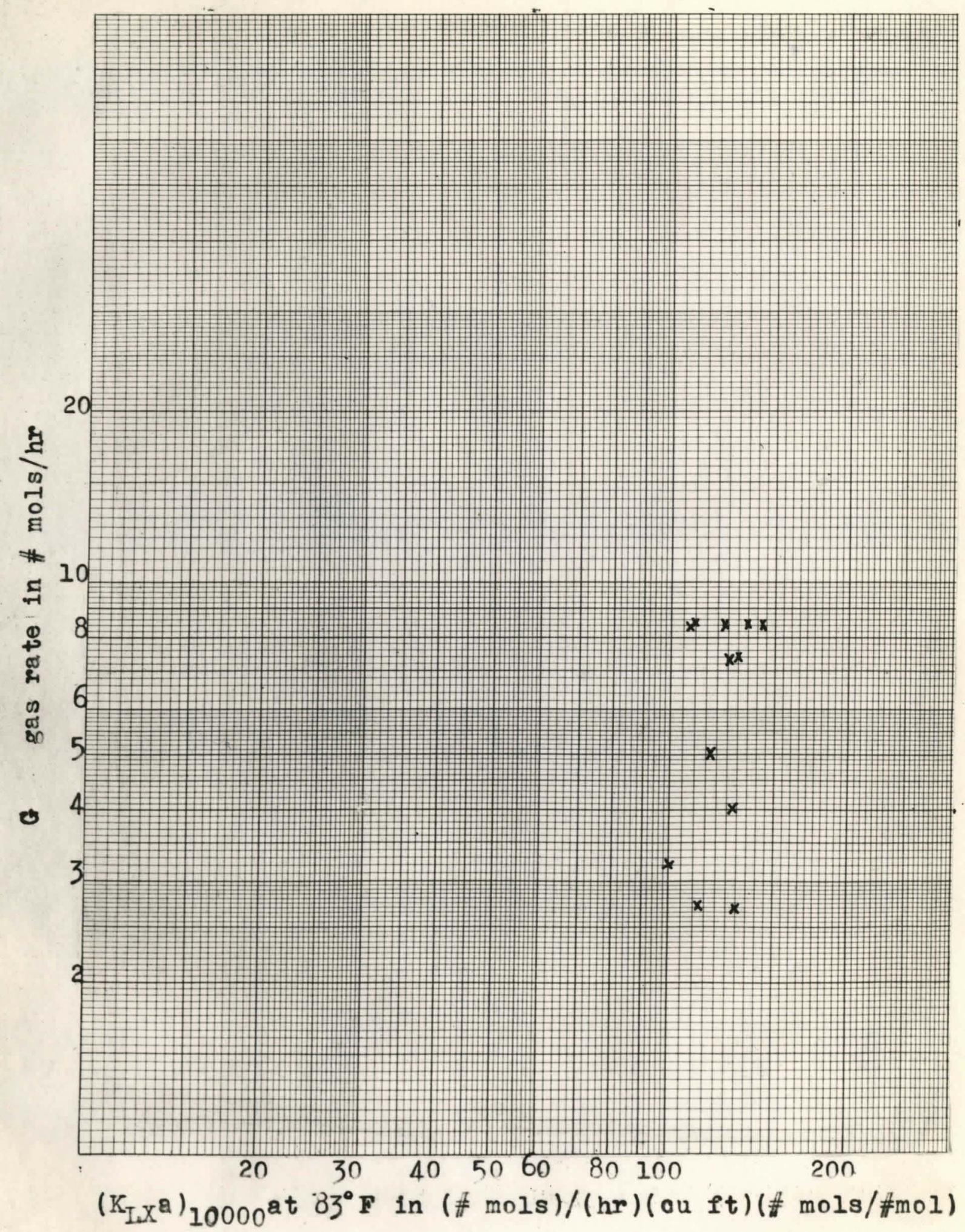

Figure 6, Transfer Coeffioient versus Gas Rate 
LITERATURE CITED 


\section{Literature Cited}

(1) Sherwood, T.K., "Absorption and Extraction", lst Edition, page 170, MoGraw-H1Il, 1937

(2) Whitman, W. G., Chem. \& Met. Eng., 29, 147, (1923)

(3) Whitman, W. G., Ind. Eng. Chem., 16, 1215, (1924)

(4) Walker, W.H., Lewls, W.K., McAdams, W.H. and Gill1land, E.R., "Principles of Chemical Engineering", Third edition, page 450, MoGraw-H111, 1937

(5) Ib1d, page 452

(6) Ib1d. Chapter XV

(7) National Research Counoil, "International Critical Tables", lst Edition, volume III, page 260, MoGraw-Hill, (1928)

(8) Perry, J.H., "ohemioal Engineors Handbook", 2nd Edition, page 1200, MoGraw-Hill, 1941

(9) Sherwood, T.K., and F.A.I. Holloway, A.I.Ch.E. Trans., 36, 57, (1940)

(10) Butcher, C.H., "The Industrial Chemist", compiled by Sherwood (1), page 133

(II) Durbin, W.F., Private Communication

(12) The Permitit Co., Private Communication, quoting as references J.A.W.W.A. 30, \#1, 105 (1938) and J.A.W.W.A. 31, \#1, 51, (1939)

(13) Amerioan Public Health Assn., "Standard Methods of Water Analysis", 8th Edition, page 69, Amerioan Publio Health Assn., New York, 1936

(14) Sherwood, T.K., "Absorption and Extraction", Ist Edition, f1gure 69, page 182, MoGraw-H111, 1937 
Literature Cited (Cont.)

(15) Walker, W.H., Lewls, W.K.; HeAdems, M.K.; and Gilliland, E.R., "Principles of Chemical Engineering", 3rd Edition, page 447, McGraw-I111, 1937

(16) Perry, J. H., "Chemical Enginsers Handbook", 2nd Edition, FEge 848, MoGraw-H111, 1941 
APFENDIX 
LIST OF SYMBOLS

\begin{tabular}{|c|c|c|}
\hline & & Units \\
\hline A & Area of interface & $s q \cdot f t$ \\
\hline a & $\begin{array}{l}\text { Area of interfacial surface } \\
\text { per unit volume }\end{array}$ & $s q \cdot f t \cdot / c u \cdot f t$ \\
\hline$c_{1}$ & $\begin{array}{l}\text { Concentration of solute in } \\
\text { liquid at interface }\end{array}$ & Ib.mols/cu.ft. \\
\hline $\mathrm{C}_{\mathrm{L}}$ & $\begin{array}{l}\text { Concentration of solute in } \\
\text { the main body of the liquid }\end{array}$ & $1 \mathrm{~b} \cdot \mathrm{mols} / \mathrm{cu} \cdot \mathrm{ft}$ \\
\hline$c^{*}$ & $\begin{array}{l}\text { Liquid concentration in equi- } \\
\text { Iibrium with the main body of } \\
\text { gas }\end{array}$ & lb.mols/cu.ft. \\
\hline G & $\begin{array}{l}\text { Lb.mols of solute-free gas } \\
\text { per hr. }\end{array}$ & $1 \mathrm{~b} \cdot \mathrm{mols} / \mathrm{hr}$ \\
\hline $\mathrm{K}_{\mathrm{G}}$ & $\begin{array}{l}\text { Overall transfer coefficient } \\
\text { expressed in terms of gas } \\
\text { partial pressure }\end{array}$ & $\begin{array}{l}1 \mathrm{~b} \cdot \operatorname{mols} /(\mathrm{hr} \cdot) \\
(\mathrm{sq} \cdot \mathrm{ft} \cdot)(\mathrm{atm})\end{array}$ \\
\hline $\mathrm{K}_{\mathrm{L}}$ & $\begin{array}{l}\text { overall transfer coefficient, } \\
\text { axpressed in terms of liquid } \\
\text { concentration }\end{array}$ & 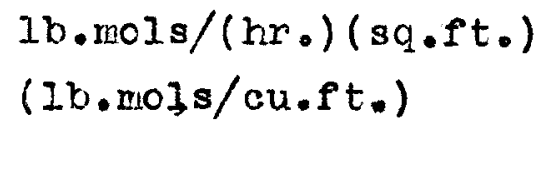 \\
\hline $\mathrm{K}_{G Y}$ & $\begin{array}{l}\text { Overall transfer coefficient, } \\
\text { expressed in terins of } Y\end{array}$ & $\begin{array}{l}\text { lb.mols } /(h r .)(s q \cdot f t .) \\
\text { (unit } \Delta Y)\end{array}$ \\
\hline $\mathrm{K}_{G X}$ & $\begin{array}{l}\text { Overall transfer coefficient, } \\
\text { expressed in terms of } x\end{array}$ & $\begin{array}{l}1 \mathrm{~b} \cdot \mathrm{mols} /(\mathrm{hr} \cdot)(\mathrm{sq} \cdot \mathrm{ft} .) \\
(\text { unit } \Delta \mathrm{X})\end{array}$ \\
\hline $\mathbf{k}_{\mathrm{G}}$ & $\begin{array}{l}\text { Transfer coefficient for the } \\
\text { gas phase }\end{array}$ & $\begin{array}{l}\text { Ib.mols } /(\mathrm{hr} \cdot)(\mathrm{sq} \cdot f \mathrm{t} \cdot) \\
(\mathrm{atm})\end{array}$ \\
\hline${ }^{k}$ & $\begin{array}{l}\text { Transfer coefficient for the } \\
\text { liquid phase }\end{array}$ & 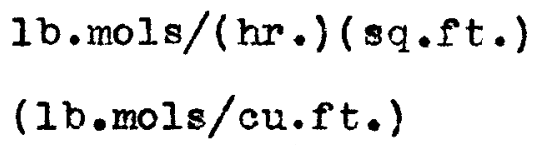 \\
\hline
\end{tabular}


IIST OF SYMBOLS (CONT.)

Units
$\left(K_{L X}^{2)} 10,000 K_{L X}\right.$ recalculated to a llquid flow$$
\begin{aligned}
& \text { of } 10,0001 \mathrm{lo} / \mathrm{sq} . \mathrm{ft} \\
& \mathrm{K}_{\mathrm{LX}}{ }^{\mathrm{a}}\left[\frac{1 \mathrm{C}, 000}{\mathrm{I}_{S}}\right]^{.85}
\end{aligned}
$$
Ib.mols $/(\mathrm{hr} \cdot)$
(cu.ft.)(Ib.mols)
13.mol)
I Lb.mols of solute-free Ilquid
per $\mathrm{hr}$. $1 \mathrm{~b} \cdot \mathrm{mols} / \mathrm{hr}$.
$\mathbf{L}_{\mathbf{s}}$
Lb. liquid per hr. per sq.ft. $1 \mathrm{bs} \cdot /\left(\mathrm{rr}_{\bullet}\right)$
cross-section of tower (sq.ft.)
1 Height of tower in feet ft.
$\mathrm{N}_{\mathrm{A}}$ Fate of transfer of component $\mathrm{a} \quad \mathrm{lb} . \mathrm{mols} / \mathrm{hr}$.
$F_{1} \quad$ Partial pressure of solute at
the interface atm.
$\mathrm{p}_{\mathrm{G}} \quad$ Partial pressure of solute in
body of the gas atm.
p* Partial pressure of solute gas in
equilibrium with main body of the
liquid
atm.
P Total pressure atm.
$r_{L} \quad$ Resistance to mass transfer in the
liquid, from the body of the Jiquid (hr.)(sq.ft.)
to the interfaca
(Ib.mol/cu.ft.)/
Ib.mol
$r_{G} \quad$ Resistance to mass transfer in the (hr.)(sq.ft.)
ges, from the body of the gas to (atm)/1b.nol
the interface
s
vrossectional area of tower
sq.ft.
$\mathrm{X}$
Concentration of solute in liquid
1b.mols/1b.mol 
IIST OF SVIABOLS (CONT.)

Units

Y

$\mathrm{X*}$

Y*

$(\Delta \mathrm{X}) \mathrm{av}$
Concentration of solute in gas $1 \mathrm{~b} . \mathrm{mols} / 1 \mathrm{~b} . \mathrm{mol}$ Equilibrium value of $X$ corresponding to $Y$ Ib.mols/In.mol Equilibrium value of $Y$ corresponding to $x$ Ib.mols/1b.mol. Lcgarithmic mean driving force 


\section{CALIBRATION OF WATER METER}

The water meter consists of a .703 inch sharpedged orifice in a staridard $2^{\prime}$ pipe (2.neq" I.D.), with throat connections.

Using the besic equation of the A.S.M.E. Special Research Committee on Fluid Meters (13)

$$
w=\operatorname{cY}_{2} \sqrt{\frac{2 g_{c}\left(p_{1}-p_{2}\right) \rho_{1}}{1-\beta^{4}}}
$$

where

w Weight rate of discharge in 1 b. mass/sec

C Coefficient of discharge (no dimensions)

$Y$ Expansion fector (no dimensions)

A Crossectional opening of discharge araa in sq.ft.

${ }_{\mathrm{C}}$ Dimensional constant $32.174(1 \mathrm{~b} . \mathrm{mess})(\mathrm{ft.}) /$ (1b. force) (sec) $)^{2}$

$p_{1}, p_{2}$ Pressures at upstream and downstream pressure taps respectively in 1b. force/sq.ft.

$P_{I}$ Density at upstream tempereture and pressure in $1 b$. mass/cu.ft.

B Ratio (for circular opernings) of diameter of constriction to diameter of upstream pipe

$$
\begin{aligned}
c & =.61 \\
Y & =1 \\
A_{2} & =\left(\frac{.703)^{2}}{12}\right)^{2}\left(\frac{3.14}{4}\right)=.0026955 \mathrm{sq} . \mathrm{ft} . \\
2 \mathrm{~g}_{\mathrm{C}} & =64.34 \\
\beta & =\frac{.703}{2.067}=.3401 \quad \beta^{4}=.01338 \quad 1-\beta^{4}=.98662
\end{aligned}
$$




$$
\begin{aligned}
w= & \sqrt{p_{1}-p_{2}}(.61)(.002955) \sqrt{(64.34)(62.35) / .98662} \\
= & \sqrt{p_{1}-p_{2}}(.10432) \\
& \text { If } p_{1}-p_{2} \text { is expressed in inches of mercury under }
\end{aligned}
$$

water, expressed as $\mathrm{h}$

$$
\begin{aligned}
w= & \sqrt{\frac{h\left(\frac{12.6}{12}\right) 62.3}{12}(.10432)}=.844 \sqrt{h} \\
\text { w In } \# / h r= & (3600)(.844) \sqrt{h}=3038 \sqrt{h} \\
& \text { This is the "theoretical" curve in figure } 7 .
\end{aligned}
$$

TABLE 3

WATER METER CALIBRATION DATA

TIme

30 seconds

30 seconds

30 seconds

30 seconds

30 seconds

30 seconds
\#Water Welghed

36\#

53.5

28.25

91.5

121

137.5
Manometer Reading \# Water/hr. 1.87 inches $\mathrm{Hg}$. $\quad 4320$

4.1 " " 6420

1.2

3390

10980

14520

16500

The data of $T_{a b l e ~} 5$ are plotted in figure 7 . The calibration curve so obtained is

$\mathrm{w}$ in $\# / \mathrm{hr} .=3160 \sqrt{\mathrm{h},} 4 \%$ higher than the theoretical curve. 


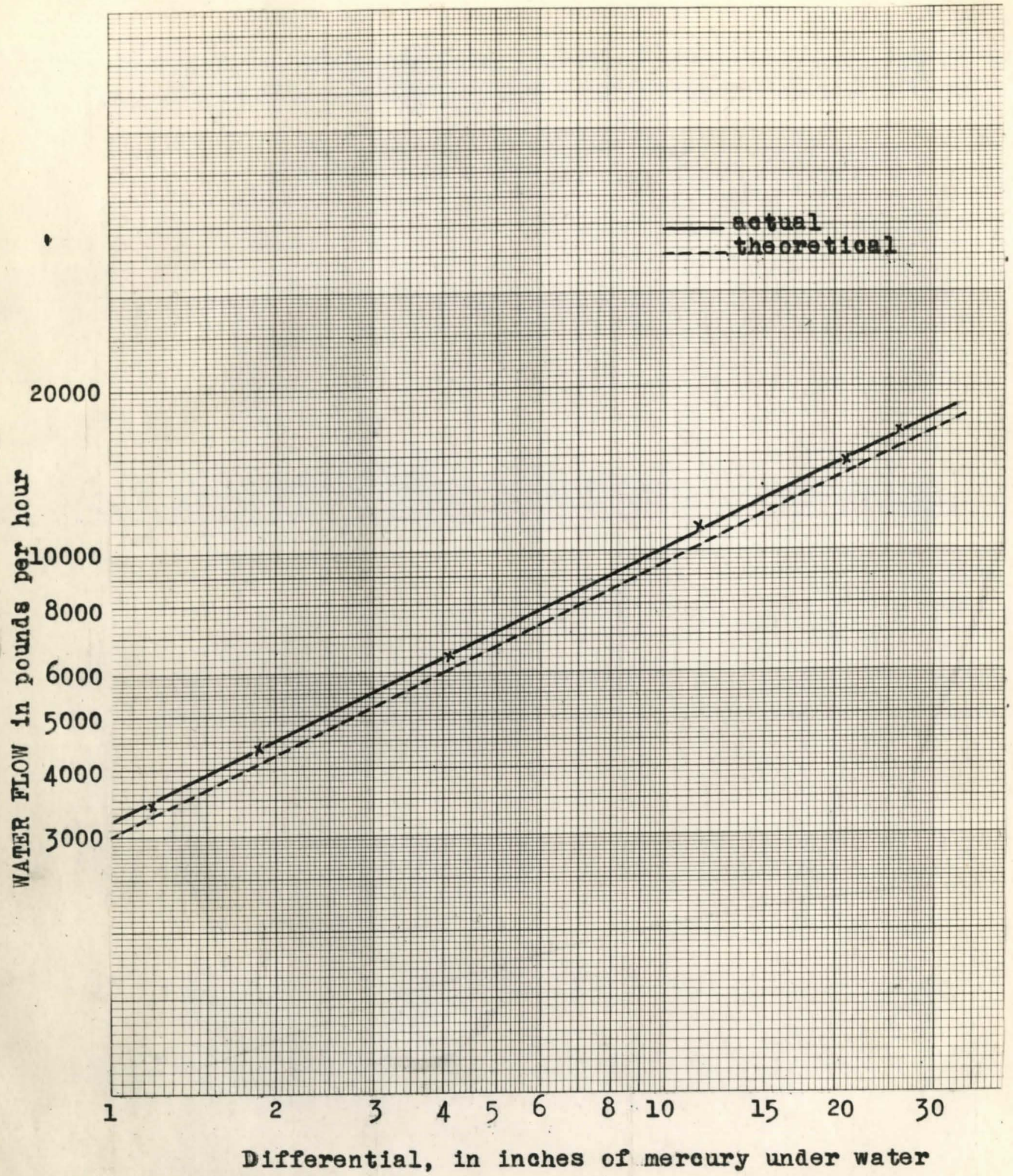

Figure 7, Calibration of Water Flow Meter 


\section{GAS FLOW METER}

No calibration was made of this meter which consists of a $1.125^{\prime \prime}$ sharp edged orifice in a standard $4^{n}$ pipe glange, throat connections.

The same formula (13) is ueed in computing flow thru this meter as in the case of the water meter

$$
\begin{aligned}
& w=\operatorname{cYA}_{2} \sqrt{\frac{2 g_{C}\left(p_{1}-p_{2}\right) \rho_{1}}{1-B^{4}}} \\
& C=.61 \text { (for Re。 above } 30,000 \text { ) } \\
& \left.Y=\frac{1-\left(p_{1}-p_{2}\right)}{\left(p_{1} k\right.}\right)\left(.41+0.35 \beta^{4}\right)=1-\left(\frac{p_{1}-p_{2}}{\left(p_{1}\right)}\right) .2943 \\
& A_{2}=\text { sree of orifice }=\frac{(1.125)^{2}}{\left(\frac{I I}{12}\right)} \frac{(I)}{(4)}=006903 \mathrm{sq} \cdot \mathrm{ft} \text {. } \\
& g_{c}=32.174 \\
& \beta=\frac{D_{0}}{D_{1}}=\frac{1.125}{4.025}=.2794 \quad \beta^{4}=.006095 \\
& 1-\beta^{4}=.9939 \\
& w=Y \sqrt{\left(p_{1}-p_{2}\right) \rho_{1}} \quad(.61)(.006903) \sqrt{\frac{64.34}{.9939}} \\
& =.03388 \Psi \sqrt{\left(p_{1}-p_{2}\right) \rho_{1}}
\end{aligned}
$$

If $h$ is differential pressure in inches of water at $20^{\circ} \mathrm{C}$

$$
w=Y \sqrt{h P_{I}} \sqrt{5.19}(.03388)=.07718 Y \sqrt{h P_{1}}
$$

\#/ secona.

This formula used in calculating gas flow. 
CALCULATIONS ON KUN \#I

Gas samples, leaving absorber

Volume of Sample $\mathrm{MI} \mathrm{Ba(OH})_{2} \quad \mathrm{MI} .107 \mathrm{~N} \mathrm{HCl} \% \mathrm{CO}_{2}$

\begin{tabular}{|c|c|c|c|}
\hline $522.3-10$ & 10 & 1.3 & 8.76 \\
\hline $510.5-10$ & 10 & 0.3 & 9.25 \\
\hline $520.8-10$ & 10 & 0.3 & 9.08 \\
\hline $521.6-10$ & 10 & 1.6 & 8.76 \\
\hline
\end{tabular}

$26.75 \mathrm{ml} \quad .10003 \mathrm{~N} \mathrm{NaOH}$ (standardized agalnst $B$ of $\mathrm{S}$ benzolo acid) required $25.10 \mathrm{ml}$ of $\mathrm{HCl}$. NF of $\mathrm{HCl} .107$. $10 \mathrm{ml}$ of $\mathrm{Ba}(\mathrm{OH})_{2}$ required $35.4 \mathrm{ml}$ of $.107 \mathrm{~N} \mathrm{HCl}$.

Water samples, leaving absorber

Volume of Sample $\mathrm{MI} \mathrm{Ba(OH})_{2} \mathrm{MI.107} \mathrm{N} \mathrm{HCl} \mathrm{Ml.107} \mathrm{NHCl} \mathrm{CO}_{2}$ in equiv. to sample $\mathrm{CO}_{2} \quad \mathrm{gCO}_{2} / \mathrm{ml}$

$\begin{array}{rrrrrr}530.5-50 & 50 & 170.8 & 37.0 & .0001735 \\ 344 & -25 & 25 & 74.3 & 29.6 & .000219 \\ 336 & -25 & 25 & 84.8 & 19.1 & \frac{.000145}{.0001792} \\ & & & \text { Ave. } & \mathrm{gCO}_{2} / \mathrm{ml}\end{array}$

$25 \mathrm{ml}$ of baryta water required $103.9 \mathrm{ml}$ of $.107 \mathrm{~N} \mathrm{HCl}$

Water sample, entering absorber

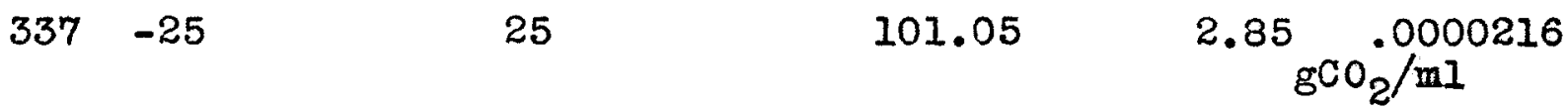

Alr Meter

Average differential $9.83^{\prime \prime} \mathrm{H}_{2} \mathrm{O}$, upstream static $9.2^{\prime \prime} \mathrm{H}_{2} \mathrm{O}=.68^{\prime \prime} \mathrm{Hg}$. 
Average a ir temperature $21.5^{\circ} \mathrm{C}$, Barometric pressure $29.40^{n} \mathrm{Hg}$.

Water temperature $10.5^{\circ} \mathrm{C}$

Assume entering air to be saturated with water vapor at $10.5^{\circ} \mathrm{C}$ partial pressure of water at $10.5^{\circ} \mathrm{C}=9.521 \mathrm{~mm} \mathrm{Hg}$. $(25.4)(29.4)$

Weter Vapor

$\%$

1.27

8.95

$\mathrm{CO}_{2}$

Dry Air

89.78
Mol Wt.

18 .228

$44 \quad 3.96$

$29 \quad 26.05$

gas passing thru meter. W111 use 30.2

$$
\begin{aligned}
& w=.07718 Y \sqrt{h P_{1}} \\
& Y=1-\frac{\left(p_{1}-p_{2}\right)}{\left(\frac{p_{1}}{p_{1}}\right)}=2943=1-\frac{(9.83}{((30.08)(13.6)} .2943=.993 \\
& \left.\rho_{1}=\frac{(30.2)}{(359)} \frac{(29.4}{(29.92}\right) \frac{(273}{(294.5)}=.0785 \\
& w=(.07718)(.993) \sqrt{(9.83)(.0785)}=.0674 \# / \mathrm{sec}=242.5
\end{aligned}
$$

\#/hr.

Total mols gas $/ \mathrm{hr}=\frac{242.5}{30.2}=8.03$

$(8.03)(.9105)=7.31 \mathrm{mols} \mathrm{co}_{2}-$ free $\mathrm{gas} / \mathrm{hr}=G$ 
Water Meter

$$
\begin{aligned}
& \text { Average differential }=9.06^{n} \mathrm{Hg} \text { under water } \\
& \text { Water flow } \\
& =3160 \sqrt{9.06}=9510 \mathrm{H} / \mathrm{hr} \text {. } \\
& \text { Mols/hr } \\
& =\frac{9510}{18} 528 \mathrm{mols} / \mathrm{hr}=\mathrm{I} \\
& x_{1} \\
& =(.0001792) \frac{18}{44}=.0000733 \\
& x_{2} \\
& =(0000216) \frac{18}{44}=00000894 \\
& \mathrm{X}_{1}-\mathrm{x}_{2} \\
& =.00006436 \\
& L\left(X_{1}-x_{2}\right) \\
& =(528)(.00006436)=.034=G\left(Y_{1}-Y_{2}\right) \\
& Y_{2} \\
& =\frac{8.95}{91.05}=.0984 \\
& Y_{1} \\
& =\frac{.034}{7.31}+.0984=.1031
\end{aligned}
$$

From I.C.T. data

$$
\text { At } 10.5^{\circ} \mathrm{C} \quad \mathrm{K}=\frac{\mathrm{p}_{\mathrm{q}}}{\mathrm{x}_{\mathrm{a}}}=(.8056)\left(10^{6}\right)
$$

where $\mathrm{K}=$ Henry Law constant for $\mathrm{CO}_{2}$

$$
\begin{aligned}
& \mathrm{p}_{\mathrm{a}}=\text { Partial pressure of } \mathrm{CO}_{2} \text { in } \mathrm{mm} \mathrm{Hg} . \\
& \mathrm{x}_{\mathrm{a}}=\text { mol fraction } \mathrm{CO}_{2}
\end{aligned}
$$

Total pressure $=30.08^{\prime} \mathrm{H}_{\mathrm{g}}=764 \mathrm{~mm}$

$$
\begin{aligned}
& p_{a}=(764) \frac{.1031}{1.1031}=71.3 \mathrm{~mm} \mathrm{H} 8 \text {. where } \nabla_{1}=.1031 \\
& x_{a}=\frac{71.3}{(.8056)\left(10^{6}\right)}=(8.85)\left(10^{-5}\right)=x_{1}^{*} \\
& x_{1}^{*}-x_{1}=(8.85-7.33)\left(10^{-5}\right)=(1.52)\left(10^{-5}\right)
\end{aligned}
$$




$$
\begin{aligned}
\mathrm{p}_{\mathrm{a}} & =\frac{(764)(.0984)}{1.0984}=68.5 \mathrm{~mm} \mathrm{Hg}, \text { where } \mathrm{Y}_{2}=.0984 \\
\mathrm{x}_{\mathrm{a}} & =\frac{68.5}{(.0056)\left(10^{6}\right)}=(8.49)\left(10^{-5}\right)=\mathrm{x}_{\mathrm{*}} \\
\mathrm{x}_{2}^{*}-\mathrm{x}_{2} & =(8.49-.89)\left(10^{-5}\right)=(7.60)\left(10^{-5}\right) \\
\Delta \mathrm{x}_{\mathrm{Im}} & =\frac{(7.6-1.52)\left(10^{-5}\right)}{2.303108_{10}\left(\frac{7.6}{1.52)}\right)}=(3.775)\left(10^{-5}\right) \\
L\left(\mathrm{x}_{1}-\mathrm{x}_{2}\right) & =\mathrm{dN}=\mathrm{K}_{\mathrm{LX}} \mathrm{Is} \Delta \mathrm{x}_{1 \mathrm{~m}} \\
\mathrm{~K}_{\mathrm{LX}} & =\frac{.034}{(13.2)(1.27)(3.775)\left(10^{-5}\right)}=53.7
\end{aligned}
$$




\section{CALCULATIONS ON RUN \#4}

\section{Gas Meter}

Average differential 16.8 inches of water, air temperature $30^{\circ} \mathrm{C}$ barometer 29.0

$$
\begin{aligned}
& w \text { in } \# / \mathrm{sec}=.07718 \mathrm{Y} \sqrt{\mathrm{h} \mathrm{P}_{1}} \\
& Y \\
& \left.\left.=1-\frac{\left(p_{1}-p_{2}\right.}{p_{1}}\right) \cdot 2943=1-\frac{(16.8}{(30.24)(13.6))}\right) \cdot 2943 \\
& =.988
\end{aligned}
$$

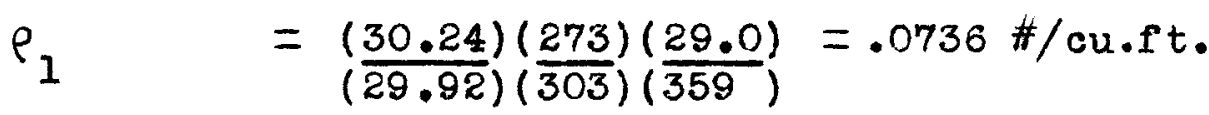

$$
\begin{aligned}
& w \quad=(.07718)(.888) \sqrt{(16.8) T .0736)}=.0847 \# / \mathrm{sec} \\
& =305 \# / \mathrm{hr} \text {. } \\
& \mathrm{mols} / \mathrm{hr} . \quad=G=\frac{305}{29}=10.52
\end{aligned}
$$

(In this run, air passing thru meter is practically $\mathrm{CO}_{2}$-free)

$$
\text { Water Meter }
$$

Average differential 4.40 inches of mercury under water. Water temperature $12^{\circ} \mathrm{C}$.

$$
\begin{aligned}
w & =3160 \sqrt{4.40}=6,620 \pi / \mathrm{hr} . \\
\mathrm{mols} / \mathrm{hr} . & =\mathrm{L}=\frac{6620}{18}=368
\end{aligned}
$$

\section{Water Analyses}

Inlet water, $\mathrm{pH} 8.24$, alkalinity $40 \mathrm{ppm}$ as $\mathrm{Ca} \mathrm{CO}_{3}$

$$
\begin{aligned}
\mathrm{pH} & =\log _{10}\left[(.1938)\left(10^{7}\right) \frac{\text { alkalinity as Ca } \mathrm{CO}_{3}}{8.24}=\log _{10}\left[(.1938)\left(10^{7}\right) \frac{40}{\mathrm{CO}_{2}}\right] ; \mathrm{CO}_{2}=\frac{(.01938)(40)}{\operatorname{ant} 110 \mathrm{log} .24}=\right.
\end{aligned}
$$

$.45 \mathrm{ppm}$ 
Outlet water, $\mathrm{pH} 6.33$, alkalinity $40 \mathrm{ppm}$ as $\mathrm{CaCO}_{3}$

$$
\begin{aligned}
\mathrm{CO}_{2} & =\frac{(1.938)(40)}{\operatorname{ant1108.33}}=36.2 \mathrm{ppm} \\
\mathrm{x}_{1} & =(36.2) \frac{(18)}{\left(\frac{18}{44}\right)} 10^{-6}=(1.48)\left(10^{-5}\right) \\
\mathrm{x}_{2} & =(.45)\left(\frac{18}{(44)} 10^{-6}=(.0184)\left(10^{5}\right)\right. \\
\mathrm{x}_{1}-\mathrm{x}_{2} & =(1.462)\left(10^{-5}\right) \\
I\left(\mathrm{x}_{1}-\mathrm{x}_{2}\right) & =(368)(1.462)\left(10^{-5}\right)=.00538
\end{aligned}
$$

Ges Anelyses

Inlet a1r $1.9 \% \mathrm{CO}_{2}$

$$
\begin{aligned}
\mathrm{Y}_{1} & =\frac{1.9}{98.1}=.01938 \\
\mathrm{Y}_{2}= & \frac{1.8}{98.2}=.01833 \\
\mathrm{Y}_{1}-\mathrm{Y}_{2}= & .00105, \mathrm{G}\left(\mathrm{Y}_{1}-\mathrm{Y}_{2}\right)= \\
& (10.52)(.00105)=.011
\end{aligned}
$$

Outlet air $1.8 \% \mathrm{CO}_{2}$

Since it is felt that the material balance on the water end is the better, $Y_{1}$ and $Y_{2}$ are recalculated on that basis.

$$
\begin{aligned}
L\left(X_{1}-X_{2}\right) & =G\left(Y_{1}-Y_{2}\right)=.00538 \\
Y_{1}-Y_{2} & =\frac{.00538}{10.52}=.000512 \\
Y_{1}+Y_{2} & =.01938+.01833=.03771 \\
2 Y_{1} & = \\
Y_{2} & =.0186
\end{aligned}
$$

at $12^{\circ} \mathrm{C} K=\frac{p_{a}}{\mathrm{x}_{\mathrm{a}}}=(.8455)\left(10^{6}\right)$ from International Critical

Tables 
where $\mathrm{K}=$ Henry's Law constant for $\mathrm{CO}_{2}$

$\mathrm{p}_{\mathrm{a}}=$ partial pressure of $\mathrm{CO}_{2}$ in $\mathrm{mm}$ of $\mathrm{Hg}$.

$\mathrm{x}_{\mathrm{a}}=$ moz fraction $\mathrm{CO}_{2}$ in solution

'lotal pressuro 29.0 inches $\mathrm{Hg} \cdot=737 \mathrm{~mm}$

$$
\begin{aligned}
& p_{a}=\frac{(737)(.0191)}{1.0191}=13.81 \mathrm{~mm} \text { (where } Y_{1}=.0191 \text { ) } \\
& x_{a}=\frac{13.81}{(.8455)\left(10^{6}\right)}=(1.545)\left(10^{-5}\right)=x_{1}^{*} \\
& x_{1}^{*}-x_{1}=(1.645-1.48) 10^{-5}=(.165)\left(10^{-5}\right) \\
& \text { where } \mathrm{Y}_{2}=.0186 \\
& p_{\varepsilon}=\frac{(737)(.0186)}{1.0186}=13.45 \mathrm{~mm} \\
& x_{a}=\frac{13.45}{(.8455)\left(10^{6}\right)}=(1.572)\left(10^{-5}\right)=x_{2}^{*} \\
& x_{2}^{*}-x_{2}=(1.572-.018)\left(10^{-5}\right)=(1.554)\left(10^{-5}\right) \\
& \Delta x_{1 m}=\frac{(1.554-.165)\left(10^{-5}\right)}{2.5 \log _{10}(1.554 / .165)}=(.62)\left(10^{-5}\right) \\
& \mathrm{K}_{\mathrm{I}, \mathrm{X}} \mathrm{a}=\frac{.00538}{(13.2)(1.27)(6.2)\left(10^{6}\right)}=51.8
\end{aligned}
$$




\section{CALCULATIONS ON RUN \#6}

\section{Cas Meter}

Average differential 13.2 Inchos of water, gas temperature $93^{\circ} \mathrm{F}$.

Gas ortering meter saturated with water vapor at $83^{\circ} \mathrm{F}$, and containirg $9.4 \% \mathrm{Co}_{2}$ (dry basis). Barometer 29.63 1nches $=753 \mathrm{~mm} \mathrm{Hg}$.

Total pressure upstream $29.63-\frac{13.2}{13.6}=30.60$ Inches $\mathrm{Hg}=776 \mathrm{~mm} \mathrm{Hg}$; vapor pressure of $\mathrm{H}_{2} \mathrm{O}$ at $83^{\circ} \mathrm{V}=$ $1.13^{\prime \prime} \mathrm{H}_{2} \mathrm{O}$

Composition of Gas

$$
\% \text { Mol wt. } \frac{(\operatorname{Mol})(\%)}{100}
$$

Water Vapor

$(100)(1.13 / 30.60)=3.69$

$\mathrm{CO}_{2}$

$(.9631)(9.4)=9.05$

.18

0.675

Dry Air

$$
(.9631)(90.6)=87.20
$$

44

3.93

29

25.35

Ave. Mol Wt. 30.005 (use

w in $\# / \mathrm{sec}=(.07718)(\mathrm{Y}) \sqrt{\mathrm{h} \mathrm{P}_{1}}$

$$
\begin{aligned}
& \left.Y=1-\frac{\left(p_{1}-p_{2}\right.}{p_{1}}\right)(.2943)=1-\left(\frac{13.2}{(30.6)(13.6)}\right) \\
& (.2943)=.989
\end{aligned}
$$

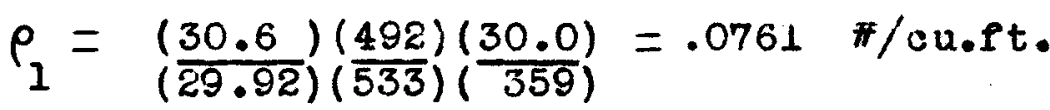

$$
\begin{aligned}
& w=(.07718)(.989) \sqrt{(13.2)(.0761)} \\
& =.0765 \# / \mathrm{sec}=275.5 \# / \mathrm{hr} \text {. } \\
& \mathrm{mols} / \mathrm{hr}=\frac{275.5}{30.0}=9.18
\end{aligned}
$$

mols $\mathrm{CO}_{2}$-free gas/hr. $=(.9095)(9.18)=8.35=\mathrm{G}$ 
Average differential 4.2 inches or mercury under

water.

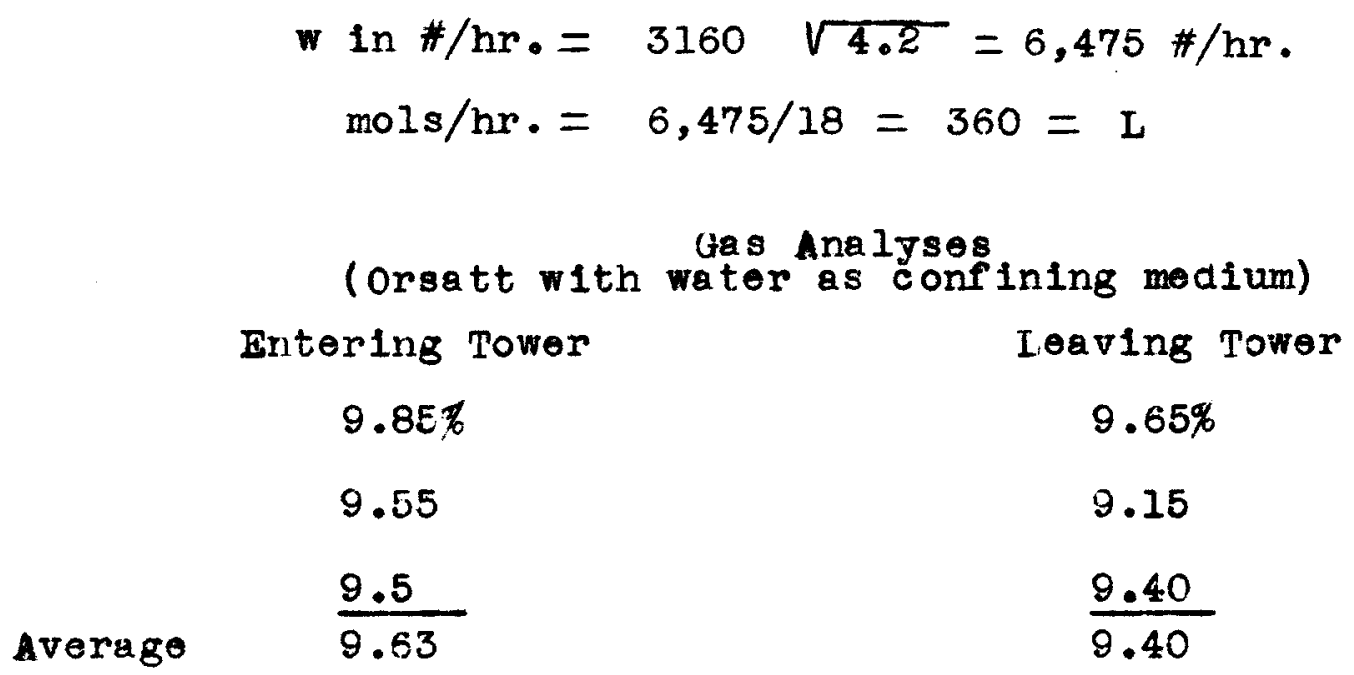

Water Analyses

$100 \mathrm{ml}$ samples titrated to phenolphthalein endpoint using standard $\mathrm{NaOH}, 1 \mathrm{ml}=.956 \mathrm{mg} \mathrm{CO}_{2}$, standardized against Bureau of Stundards benzolc acid.

Entering Tower

Leaving Tower

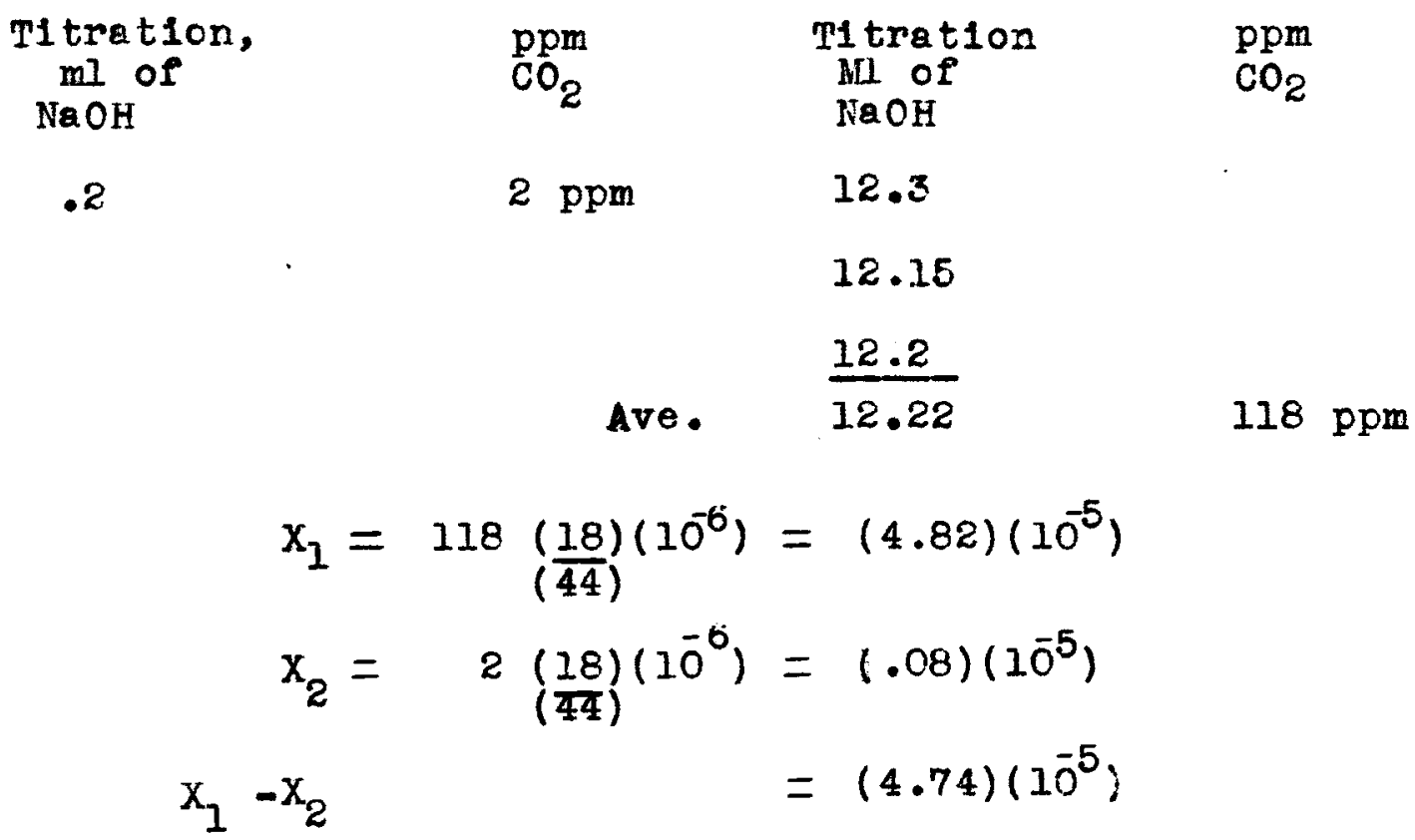




$$
\begin{aligned}
& L\left(x_{1}-x_{2}\right)=(360)(4.74)\left(10^{-5}\right)=.01708 \\
& Y_{1}=\frac{(8.63)(.9631)}{100-(8.63)(.0631)}=.1021 \\
& \mathrm{Y}_{2}=\frac{(9.4)(.9631)}{100-(9.4)(.9631)}=.0994 \\
& \mathrm{Y}_{1}-\mathrm{Y}_{2} \quad=.0027 \\
& G\left(Y_{1}-Y_{2}\right)=(8.35)(.0027) \quad=.0225
\end{aligned}
$$

Recalculating ${ }_{1}$ \& $\mathrm{Y}_{2}$ on basis of material belance in liquid phas.

$$
\begin{array}{rlrl}
L\left(X_{1}-X_{2}\right) & =G\left(Y_{1}-Y_{2}\right) & & =.01708 \\
Y_{1}-Y_{2} & =\frac{.01708}{8.35} & & =.002045 \\
Y_{1}+Y_{2} & =.1021+.0984 & & =.2015 \\
2 Y_{1} & & =.20355 \\
Y_{1} & =.1018 \\
Y_{2} & =.1018-.00205 & =.0997 \\
\text { At } 83^{\circ} H^{\prime}=28.3^{\circ} \mathrm{C} & \\
K & =\frac{p_{2}}{X_{2}}=(1.353)\left(10^{6}\right) &
\end{array}
$$

where $K=$ Henryis Law constant, $p_{a}=$ partial pressure of $\mathrm{CO}_{2}$ in $\mathrm{mm}$ of $\mathrm{Hg}$, and $\mathrm{x}_{\mathrm{a}}=$ mol fraction of $\mathrm{CO}_{2}$ in liquid phase.

$$
\begin{aligned}
\text { where } \mathrm{Y}_{1} & =.1018 \quad \mathrm{p}_{\mathrm{a}}=\frac{(753) \cdot 1018}{1.1018}=69.5 \\
\mathrm{x}_{\mathrm{a}} & =\frac{69.5}{(1.353)\left(10^{6}\right)}=(5.13)\left(10^{-5}\right)=\mathrm{x}_{1}^{*} \\
\mathrm{x}_{1}^{*}-\mathrm{x}_{1} & =(5.13-4.82)\left(10^{-5}\right)=(.31)\left(10^{-5}\right)
\end{aligned}
$$




$$
\begin{aligned}
\text { where } \mathrm{y}_{2} & =.0997 \quad \mathrm{p}_{\mathrm{a}}=\frac{(753)(.0997)}{(1.0997)}=68.1 \\
\mathrm{x}_{2} & =\frac{68.1}{(1.353)\left(10^{6}\right)}=(5.02)\left(10^{-5}\right)=\mathrm{x}_{2}^{*} \\
\mathrm{x}_{2}^{*}-\mathrm{x}_{2} & =(5.02-.08)\left(10^{-5}\right)=(4.94)\left(10^{-5}\right) \\
\Delta \mathrm{x}_{1 \mathrm{~m}} & =\frac{(4.94-.31)\left(10^{-5}\right)}{\left.2.310 \mathrm{l} \frac{(1.94}{(.31)}\right)}=(1.672)\left(10^{-5}\right) \\
\mathrm{K}_{\mathrm{I} \mathrm{X}^{2}} & =\frac{.01708}{(13.2)(1.27)(1.672)\left(10^{-5}\right)}=60.8
\end{aligned}
$$


ACKNOWLEDGMENTS 
This is to acknowledge the help and assistance of Dr. R. C. Ernst in direction of this work.

This study would not have been possible without the help of the Loulsvilie Gas and Electric company whose donation of the absorber shell and packing are hereby acknowl$\theta \mathrm{d} g e d$

Acknowledgments are also due Dr. E. E. Iitkenheus, Dr. G. C. Williams and Mr. Wilson R. Barnes for their kind advice and suggestions. 
FATHER'S NAME:

MOTHER'S NAME :

DATE CF BIRTH:

PLACE OF BIRTH:

ELIMENTARY SCHOOLS:

UNIVEPSITIES:

EMPLOYED BY:
HIGH SCHOCL :

Preston T. Aker (Deceased)

Florence Lee Aker (Deceased)

June 17,1902

Smithvilio, Missouri

Smithvilie, Missouri public school 'thomas Hart Benton School, Kansas

C1ty, Mo., Graduated, 1916

Central High School, Kanses City, Mo. Graduated 1920

University of Missours 1920-21

University of Illinols 1922-26

B. S. In Ch. E.

1926

Louisville Gas \& Electric Co. 1925 -

Titlo: Chemical Engineer

FIELDS OF SPECIATIZATION: Water conditioning, corrosion prevention, boller water conditioning. Manufectured and Natural gases.

MAJOR WORK DONE AT UNIVERSITY OF LOUISVILLE UNDER:

$$
\begin{aligned}
& \text { Dr. R. C. Ernst } \\
& \text { Dr. G. C. Williams } \\
& \text { Dr. E. E. IItkenhaus }
\end{aligned}
$$

